\title{
Metodika pro hodnocení environmentální výchovy pro dospělé účastníky
}

Jan Činčera

Envigogika 8 (5) - Metodiky/Methodologies

Publikováno/Published: 31. 12. 2013

DOI: http://dx.doi.org/10.14712/18023061.415

\begin{abstract}
Abstrakt
Metodika předkládá souhrn nástrojů pro evaluaci programů environmentální výchovy určených pro dospělé účastníky. Charakterizuje specifika práce s touto cílovou skupinou a vymezuje relevantní proměnné environmentální výchovy. Poukazuje na rozdíly $v$ evaluaci komunitně zaměřených programů, profesního vzdělávání a programů environmentální interpretace. Porovnává a hodnotí strategie pro jejich kvantitativní i kvalitativní evaluaci. Uvádí príklady z domácích i zahraničních evaluačních výzkumů.
\end{abstract}

\section{Klíčová slova}

evaluace, kvantitativní, kvalitativní, programy

\begin{abstract}
The methodology provides a comprehensive overview of instruments aimed for evaluation of environmental education programmes for adults. It introduces specific featurs of evaluation of programmes focused on this target group and defines relevant variables for environmental education. It compares and contrasts differences between evaluation of community-based programmes, professional training courses, and environmental interpretation programmes. It compares and discusses strategies for their quantitative and qualitative evaluation. Examples of evaluation research from Czech and abroad are provided.
\end{abstract}

\section{Key words}

evaluation, qualitative, quantitative, programme 


\section{METODIKA PRO HODNOCENÍ PROGRAMŮ ENVIRONMENTÁLNÍ VÝCHOVY PRO DOSPĚLÉ ÚČASTNÍKY}

Jan Činčera, Masarykova univerzita Brno, Katedra environmentálních studií, 2013

\section{OBSAH}

Úvod 3

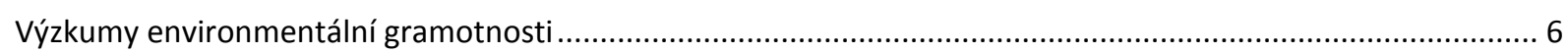

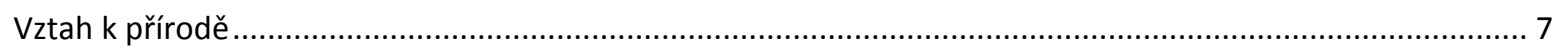

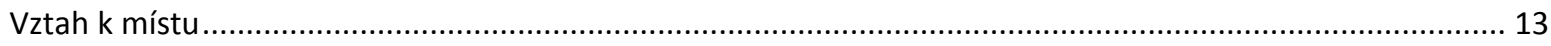

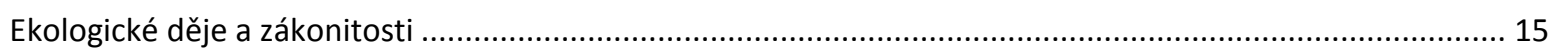

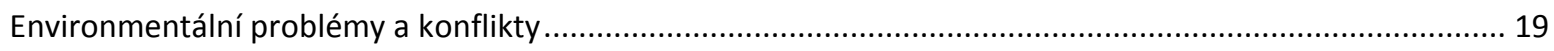

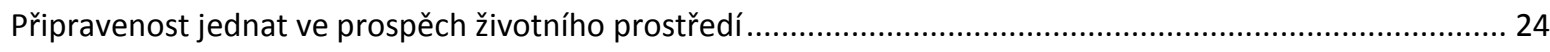

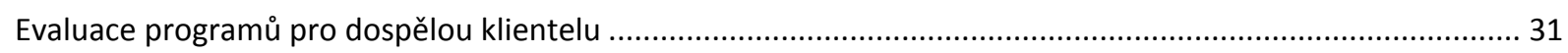

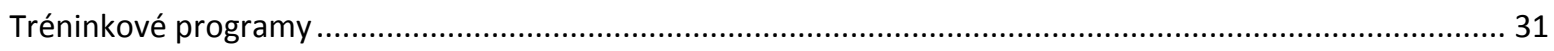

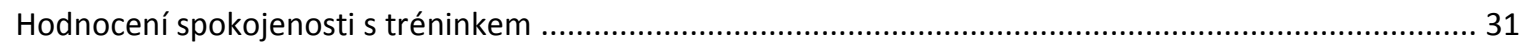

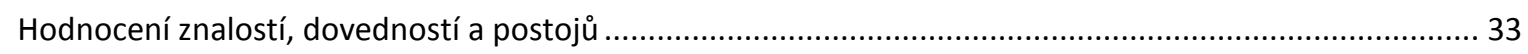

Hodnocení vlivu programu na chování absolventů a dlouhodobé dopady programu.............................. 35

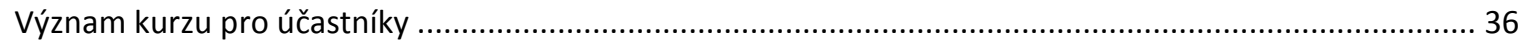

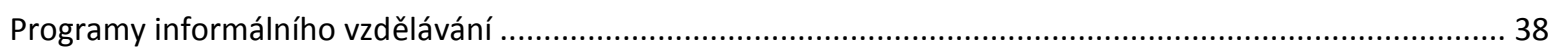

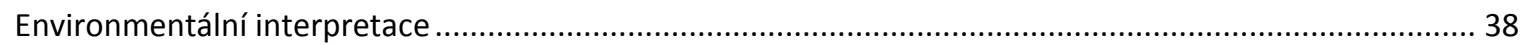

Informální programy v zoologických a botanických zahradách .................................................... 39

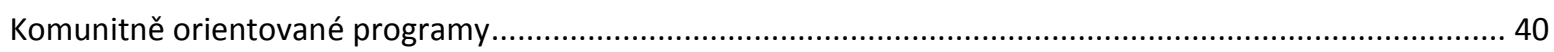

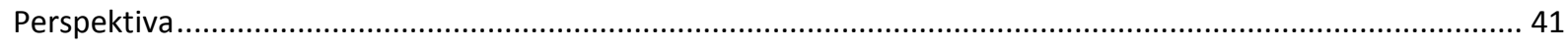

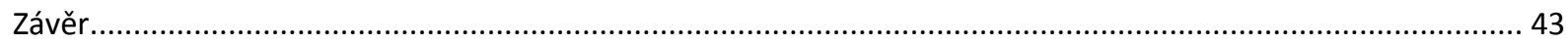

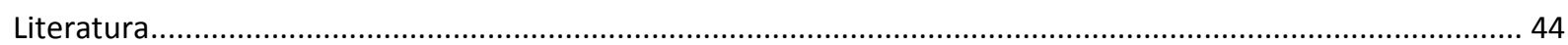


Př́loha č. 1 EBS - 2 


\section{ÚVOD}

Předkládaná metodika je jedním z výstupů projektu TAČR „Hodnocení efektivity nástrojů environmentálního vzdělávání, výchovy a osvěty (EVVO)“, řešícího výzkumnou potřebu Ministerstva životního prostředí. Je určená pro formativní i sumativní evaluace programů environmentální výchovy určené pro věkovou skupinu předškolního a mladšího školního věku. Předpokládá, že jejími uživateli budou zejména:

- Interní evaluátoři ze středisek ekologické výchovy;

- Subjekty poskytující finanční podporu programů EVVO;

- $\quad$ Externí evaluátoři z neziskových organizací, vysokých škol či jiných subjektů;

- Studenti a vyučující na vysokých školách zaměřující se na výzkum v oblasti environmentální výchovy.

Efektivní využití metodiky vyžaduje určité vstupní kompetence na straně uživatele. Těmi jsou především:

- Základní orientace v problematice EVVO, zejména v oblasti porozumění cílů EVVO a znalost běžných typů nabízených programů EVVO;

- Znalost základních principů analýzy a evaluace programu EVVO (Činčera, 2010);

- Znalosti a dovednosti voblasti metodologie výzkumu v sociálních vědách, zejména schopnost zpracovávat jednoduchá statistická data (např. testy statistické významnosti) a získávat a analyzovat kvalitativní data (např. pomocí kódovacích technik).

Metodika není vhodná pro:

- Programy neodpovídající uvedené cílové skupině;

- Programy zaměřené primárně na jiné výchovně-vzdělávací oblasti, než je EVVO;

- Služby nebo jiné typy produktů, které nemají charakter programu, tj. postrádají jasně definované cíle a aktivity, které mají vést $\mathrm{k}$ jejich naplnění.

Evaluace programů environmentální výchovy je jedním ze základních předpokladů jejich efektivity. Hodnocení může prokázat, že předpoklady, vkládané do vztahu mezi cíli a aktivitami programu fungují podle očekávání a program je žádoucí dále nabízet. Stejně tak ale mohou prokázat, že v důsledku chyb v teorii či implementaci program nefunguje a je zapotřebí jej změnit. Bez zavedení systému pravidelných evaluací programů proto není systém environmentální výchovy v žádné zemi dlouhodobě udržitelný.

Z laického pohledu se programy environmentální výchovy zaměřují především na děti. Ve skutečnosti jsou dospělí, at již v roli účastníků, realizátorů či pozorovatelů jejich integrální součástí. Dospělí vystupují jako účastníci či cílová skupina zejména v těchto typech programů a vzdělávacích aktivit:

- Vzdělávací programy pro pedagogické pracovníky zařazené do systému dalšího vzdělávání pedagogických pracovníků (DVPP);

- Programy zaměřené na vzájemnou výměnu profesních zkušeností v oblasti environmentální výchovy (např. veletrh ekologických výukových programů);

- Programy profesního vzdělávání a tréninku v různých oblastech souvisejících s životním prostředím;

- Interpretativní programy (Ham, 1992) pro veřejnost v prírodních oblastech, zoologických zahradách, muzeích či jiných organizacích nabízející informální vzdělávání;

- Osvětově vzdělávací programy pro širokou veřejnost (např. besedy, oslavy Dne Země);

- Kampaně a jiné formy environmentální komunikace (Cox, 2009) zaměřené na př́mé ovlivňování chování veřejnosti; 
- Výuka environmentální výchovy či environmentalistiky v rámci vysokoškolského vzdělávání;

Významem a rozsahem jsou tyto programy a aktivity srovnatelné s programy pro žáky. Napríklad v roce 2011 bylo jen v rámci středisek sdružených do Sdružení středisek ekologické výchovy Pavučina (SSEV Pavučina) realizováno:

- 436 jednodenních vzdělávacích akcí pro 7013 pedagogických pracovníků a 123 pobytových vzdělávacích akcí pro celkem 1964 účastníků (Broukal a kol., 2012, s. 19);

- 905 akcí pro 172355 účastníků z řad široké veřejnosti (Broukal a kol., 2012, s. 26);

- Bylo vydáno 116 publikací o celkovém nákladu 160000 kusů (Broukal a kol., 2012, s. 27);

- 142 účastníků převážně ze středisek ekologické výchovy se účastnilo pravidelného Veletrhu ekologických výukových programů (Broukal a kol., 2012, s. 9);

- 726 škol bylo zapojeno do sítě MRKEV a dostávalo pravidelné zásilky metodických materiálů (Broukal a kol., 2012, s. 11).

Dospělí respondenti navíc mohou hrát nezastupitelnou roli i při hodnocení programů určených pro děti. Učitelé mohou obohatit evaluaci ze svoji perspektivy pozorovatele či implementátora metodických materiálů.

Ve srovnání s dětmi představují dospěli širokou a heterogenní skupinu s rozdílnými zájmy, schopnostmi a potřebami. Pro potřeby dalšího textu považujeme za účelné od sebe odlišit několik podskupin, které na programy sdílí určitý úhel pohledu.

První důležitou skupinou jsou studenti vysokých škol. Studenti jsou subjektem environmentální výchovy realizované v rámci svých studijních programů. Ty mají charakter bud' profesního tréninku, jako je třeba příprava na učitelskou profesi, nebo nepřímého ovlivňování environmentálních postojů a chování, například školní politikou v oblasti environmentálního managementu či univerzitními kurzy (srv. Adomssent, M. \& Michelsen, 2006).

Druhou skupinou jsou pedagogičtí pracovníci v oblasti formálního, neformálního i informálního vzdělávání a výchovy. Ti jsou vzděláváni bud' formou profesního tréninku, jako jsou kurzy krátké DVPP či specializační studium pro koordinátory environmentální výchovy, nebo programů založených na sociálním učení, tj. nehierarchickém informálním učení založeném na vzájemné výměně zkušeností mezi účastníky (Wals et al., 2007).

Třetí skupinu můžeme označit jako širokou veřejnost. Veřejnost může být účastníkem informálních programů, jako jsou například programy environmentální interpretace (Ham, 1992), může se účastnit různých forem profesního tréninku souvisejícího s životním prostředím, být adresátem různých forem environmentální komunikace (Cox, 2009), aktérem a spolutvůrcem emancipačně orientovaných komunitních programů (Wals, 2007, Wals et al., 2008, Wenger, 2000, Wals, 2012), atd.

Evaluační strategie využívající data od dospělé klientely musí respektovat zásadu situační responsivity (Kusters et al., 2011). Studenti vysokých škol mohou ve svých postojích, znalostech či chování představovat konzistentnější skupinu, než široká veřejnost. Současně, studenti například humanitně orientovaných škol se mohou ve svých postojích lišit od studentů technických oborů. Programy založené na „instrumentálním přistupu“ budou vyžadovat jinou evaluační strategii, než programy emancipačního charakteru (Wals, 2012).

V evaluační praxi se zpravidla setkáváme se třemi typy situací, ve kterých sbíráme data od dospělých respondentů. První se týká výzkumů environmentální gramotnosti, respektive jejich různých složek, u dospělé populace. Přestože cíle těchto výzkumů zpravidla bývají širší, mohou být využity i pro analýzu potřeb ${ }^{1}$ (front-

\footnotetext{
${ }^{1}$ Analýza potřeb může být samozřejmě zkoumána i kvalitativně. Kvantitativní výzkum nám zde umožní porozumět širšímu kontextu, tj. například tomu, zda má smysl pro danou cílovou skupinu připravovat program
} 
end evaluation) a tedy pro efektivní stanovení cílů programu (Wholey et al., 2004, Rossi et al., 2004, Simmons, 2008). V rámci této metodiky vycházíme z vymezení cílů environmentální výchovy přijatého pracovní skupinou působící při Ministerstvu životního prostředí (Broukalová a kol., 2012). Snahou pracovní skupiny bylo zpracovat takový dokument, který bude kompatibilní se zahraničním diskursem i domácí tradicí. V rámci projektu VaVal „Hodnocení efektivity nástrojů environmentální výchovy, vzdělávání a osvěty“pro Technologickou agenturu ČR byly $\mathrm{k}$ cílům nadefinovány př́klady proměnných. $V$ první části metodiky se proto budeme věnovat př́kladům nástrojů, které mohou být použity pro měření různých proměnných korespondujících s cíli environmentální výchovy.

Druhým typem situace je evaluace programu určeného pro dospělou klientelu. V závislosti na východiscích programu, Cílech programu, Cílech evaluace, velikosti skupiny a dalších kontextuálních faktorech pak evaluátor může volit kvantitativní, kvalitativní či smíšenou metodologii výzkumu. Ve druhé části metodiky se podíváme na př́ílady možných strategií.

Třetím typem jsou situace, ve kterých potřebujeme do evaluace programu pro žáky zahrnout perspektivu dospělého respondenta, tj. například doprovázejícího učitele. Jim bude věnována poslední část metodiky.

Využití této metodiky předpokládá základní znalost obecné evaluační metodologie (Bennett, 1989, Fitzpatrick et al., 2004, Frechtling et al., 2002, Stokking et al., 1999, Ernst et al., 2009, Patton, 2002, 2008, Wholey et al., 2004, Rossi et al., 2004, Simmons, 2008, Činčera, 2010). Evaluace programů představují dynamicky se rozvíjející komplex různých přístupů, mezi kterými je potřeba vybrat ten, který odpovídá dané situaci.

zaměřený na určité cíle environmentální výchovy (např. jestli vysokoškolští studenti kupují ekologicky šetrné výrobky). Kvalitativní výzkum pak může vést $\mathrm{k}$ hlubší analýze toho, jak cílová skupina přemýšlí o určitém tématu (např́klad jaké bariéry v nakupování jim brání, co si o šetrných výrobcích myslí, co si myslí o lidech, kteří je nakupují atd.). 


\section{VÝZKUMY ENVIRONMENTÁLNÍ GRAMOTNOSTI}

Pojmem „environmentální gramotnost“ zde budeme myslet komplex znalosti, dovednosti, postojů, přesvědčení či hodnot souvisejících s odpovědným environmentálním chováním, včetně odpovědného chování samotného (Disinger \& Roth, 1992, Disinger, 1997, Morrone, Mancl \& Carr, 2001; Moseley, 2000, Stables \& Bishop, 2001,Wright, 2008, Goldman, Yavetz \& Pe'er, 2006, Daudi, 2000, Hsu \& Roth, 1998). V České republice tento komplex podrobněji charakterizuje dokument Cíle a indikátory EVVO (Broukalová a kol., 2012), zpracovaný pro potřeby Ministerstva životního prostředí širokou pracovní skupinou reprezentující domácí profesní komunitu. Dokument definuje pět hlavních oblastí kompetencí pro environmentálně odpovědné jednání, tj.:

- Vztah k prírodě

- Vztah k místu

- Ekologické děje a zákonitosti

- Environmentální problémy a konflikty

- Připravenost jednat ve prospěch ŽP (Broukalová a kol., 2012).

Přestože teoreticky můžeme u dospělých respondentů ověřovat všechny, většina výzkumů se zaměřuje na měření proměnných souvisejících se vztahem k prrírodě a připraveností jednat ve prospěch životního prostředí. Méně často se můžeme setkat s výzkumy ověřujícími znalosti environmentálních problémů a konfliktů. Ověřování znalostí a dovedností v oblasti ekologických dějů a zákonitostí pak je nejméně obvyklé.

V souladu s tím měří většina existujících nástrojů proměnné týkající se první a poslední oblasti kompetencí. Je třeba znovu připomenout problémy, související s různorodostí této cílové skupiny. Nástroj, který je ověřený pro jeden typ cílové skupiny, nemusí automaticky fungovat pro jinou skupinu, př́padně skupinu stejného typu, ale z jiného socio-kulturního prostředí. 
VZTAH K PŘÍRODĚ

V rámci dokumentu Cíle a indikátory EVVO (Broukalová a kol., 2012) bylo pro oblast Vztah k přírodě definováno několik rámcových cílů (v. tab. č. 1). Tab. č. 2 uvádí příklady proměnných, které mohou být použity pro jejich ověřování. V rámci následujícího textu budou uvedeny strategie pro evaluaci některých z uvedených proměnných.

Tab. č. 1 Vztah k přírodě v Cílech a indikátorech EVVO

\begin{tabular}{|c|c|c|}
\hline Rámcový cíl & $\begin{array}{l}\text { Vysvětlující komentář (je nutno brát jako } \\
\text { pouze ilustrativní a indikativní výklad) }\end{array}$ & $\begin{array}{l}\text { Orientační příklady možností ověření, } \\
\text { popř. indikátorů (co je například } \\
\text { možné vyhodnocovat a jakým } \\
\text { nástrojem) }\end{array}$ \\
\hline $\begin{array}{l}\text { Potřeba kontaktu } \\
\text { s př́rodou }\end{array}$ & $\begin{array}{l}\text { - Zájem vyhledávat kontakt s přírodou a } \\
\text { trávit v ní volný čas. }\end{array}$ & $\begin{array}{l}\text { - Množství volného času tráveného } \\
\text { v prírodě (dotazník, rozhovor, } \\
\text { portfolio). } \\
\text { - Analýza výpovědí o subjektivním } \\
\text { prožívání vztahu k prírodě } \\
\text { (rozhovor, volný text, obrazová } \\
\text { reflexe). }\end{array}$ \\
\hline $\begin{array}{l}\text { Schopnost prímého } \\
\text { kontaktu } \\
\text { s prírodním } \\
\text { prostředím }\end{array}$ & $\begin{array}{l}\text { - Připravenost pro kontakt s přírodním } \\
\text { prostředím, aby se člověk v přírodě } \\
\text { zbytečně nebál, neštítil a neprožíval } \\
\text { kontakt s prírodou jako nepohodlný } \\
\text { (zbavení pocitu strachu, odporu apod.). }\end{array}$ & $\begin{array}{l}\text { - Chování jedince či skupiny } \\
\text { v prírodě } \\
\text { pozorování). } \\
\text { - Znalost principů pobytu v prírodě } \\
\text { (dotazník). }\end{array}$ \\
\hline Citlivost k přírodě & $\begin{array}{l}\text { - Všímavost vůči dění v přírodě. } \\
\text { - Schopnost vyjádřit vlastní prožitek přírody } \\
\text { - slovní, písemné, dramatické, výtvarné, } \\
\text { apod. vyjádření osobního zážitku z } \\
\text { přímého kontaktu s prírodou. } \\
\text { - Vnímavost k potřebám živé prrírody. }\end{array}$ & $\begin{array}{l}\text { - Reflektivní zachycení prožitku } \\
\text { přírody - např. jak se v něm } \\
\text { objevuje príroda, co z př́rody, } \\
\text { v jakém kontextu (rozhovor, ústní, } \\
\text { písemná či obrazová reflexe). } \\
\text { - Kvalita péče o živý organismus } \\
\text { (strukturované } \\
\text { rozhovory). } \\
\text { - Znalosti a dovednosti pro kontakt } \\
\text { s živými tvory (dotazník). }\end{array}$ \\
\hline $\begin{array}{l}\text { Reflexe různých } \\
\text { pohledů na př́rodu, } \\
\text { postojů k ní a } \\
\text { ujasňování } \\
\text { vlastních hodnot a } \\
\text { postojů }\end{array}$ & $\begin{array}{l}\text { - Reflexe různých hodnotových a etických } \\
\text { pohledů na prírodu. } \\
\text { - Vědomí různosti postojů vůči přírodě. } \\
\text { - Schopnost analýzy hodnotových systémů - } \\
\text { jak se projevují v konkrétních situacích a } \\
\text { jak ovlivňují osobní postoje. } \\
\text { - Vyjádření vlastních hodnot ve vztahu } \\
\text { k přírodě. } \\
\text { - Ocenění významu přírody pro život } \\
\text { člověka. }\end{array}$ & $\begin{array}{l}\text { - Schopnost přiřadit k určitému } \\
\text { postoji možné hodnotové } \\
\text { východisko (test, rozhovor) } \\
\text { - Schopnost vyjádřit vlastní postoje } \\
\text { a hodnoty k danému problému } \\
\text { (analýza volného textu, eseje, } \\
\text { rozhovor). }\end{array}$ \\
\hline
\end{tabular}


Tab. č. 2 Proměnné pro Vztah k přírodě

\begin{tabular}{|c|c|c|}
\hline Rámcový cíl & Příklady proměnných & Definice proměnných \\
\hline \multirow[t]{4}{*}{$\begin{array}{l}\text { Potřeba kontaktu } \\
\text { s přírodou }\end{array}$} & Četnost návštěv přírody & $\begin{array}{l}\text { Počet návštěv respondenta v prírodě za určité } \\
\text { časové období. }\end{array}$ \\
\hline & $\begin{array}{l}\text { Pocitovaná potřeba kontaktu } \\
\text { s př́rodou }\end{array}$ & $\begin{array}{l}\text { Význam přisuzovaný kontaktu s prírodou } \\
\text { respondentem; míra spokojenosti se stávající } \\
\text { četností kontaktu s prírodou }\end{array}$ \\
\hline & Atraktivita prírody & $\begin{array}{l}\text { Intenzita zájmu respondenta o návštěvu určité } \\
\text { prírodní lokality nebo o kontakt s určitým přírodním } \\
\text { prvkem. }\end{array}$ \\
\hline & Propojení s přírodou & $\begin{array}{l}\text { Míra, do jaké se lidé cítí propojeni s prírodou, pocit } \\
\text { jednoty s prírodou }\end{array}$ \\
\hline \multirow[t]{4}{*}{$\begin{array}{l}\text { Schopnost } \\
\text { přímého kontaktu } \\
\text { s přírodním } \\
\text { prostředím }\end{array}$} & $\begin{array}{l}\text { Pocitované dovednosti pro } \\
\text { kontakt s přírodou }\end{array}$ & $\begin{array}{l}\text { Míra přesvědčení (self-efficacy) o zvládnutí } \\
\text { jednotlivých situací souvisejících s pobytem } \\
\text { v prírodě. }\end{array}$ \\
\hline & Strach z přírody & Míra obav z kontaktu s přírodním prostředím. \\
\hline & Znalosti zásad pro pobyt v přírodě & $\begin{array}{l}\text { Znalost odpovědných variant chování v konkrétních } \\
\text { situacích souvisejících s pobytem v prírodním } \\
\text { prostředí. }\end{array}$ \\
\hline & Odpovědné chování v přírodě & $\begin{array}{l}\text { Preference odpovědných variant chování } \\
\text { v konkrétních situacích souvisejících s pobytem } \\
\text { v prírodním prostředí. }\end{array}$ \\
\hline \multirow[t]{6}{*}{ Citlivost k př́rodě } & Environmentální senzitivita & $\begin{array}{l}\text { Empatická perspektiva k životnímu prostředí, starost } \\
\text { o prírodu }\end{array}$ \\
\hline & $\begin{array}{l}\text { Sympatie k prírodě (affinity with } \\
\text { nature) }\end{array}$ & Emoční vazba k přírodě \\
\hline & Vnímavost vůči prírodě & Schopnost reflektovat přírodní vjemy ve svém okolí. \\
\hline & $\begin{array}{l}\text { Pocitované dovednosti pro pro } \\
\text { péči o živé tvory }\end{array}$ & $\begin{array}{l}\text { Míra přesvědčení (self-efficacy) o zvládnutí } \\
\text { jednotlivých situací souvisejících s péčí o živé tvory. }\end{array}$ \\
\hline & Znalosti zásad pro péči o živé tvory & $\begin{array}{l}\text { Znalost odpovědných variant chování v konkrétních } \\
\text { situacích souvisejících s péčí o živé tvory. }\end{array}$ \\
\hline & $\begin{array}{l}\text { Odpovědné chování k živým } \\
\text { tvorům }\end{array}$ & $\begin{array}{l}\text { Preference odpovědných variant chování } \\
\text { v konkrétních situacích souvisejících s péčí o živé } \\
\text { tvory. }\end{array}$ \\
\hline
\end{tabular}




\begin{tabular}{|l|l|l|}
\hline $\begin{array}{l}\text { Reflexe různých } \\
\text { pohledů r na } \\
\text { př́rodu, postojů } \\
\text { k nía ujasňování si } \\
\text { vlastních hodnot a } \\
\text { postojů }\end{array}$ & Postoje k životnímu prostředí & $\begin{array}{l}\text { Pozitivní, negativní či neutrální stanoviska k ochraně } \\
\text { životního prostředí, či prírody jako celku. }\end{array}$ \\
\hline & $\begin{array}{l}\text { Schopnost analyzovat postoje } \\
\text { k životnímu prostředí }\end{array}$ & $\begin{array}{l}\text { Schopnost identifikovat na základě daných situací } \\
\text { postoje jednotlivých osob či skupin k životnímu } \\
\text { prostředía propojit je se souvisejícími hodnotami. }\end{array}$ \\
\hline
\end{tabular}

Nejznámějším nástrojem měříím environmentální postoje veřejnosti je tzv. Nové ekologické ${ }^{2}$ paradigma (NEP) (Dunlap \& van Liere, 1978, Dunlap a kol., 2000). Nástroj vzniknul na počátku 70. let 20. století, v době formování environmentálního hnutí a počátků environmentální výchovy. Autoři původně chtěli zjistit, jaké postoje a názory na životní prostředí mají vysokoškolští studenti, kteří se angažovali v akcích kolem Dne Země a environmentálních kampaních. Jejich postoje pak autoři porovnávali s běžnými, o životní prostředí se príliš nestarajícími, studenty. Výsledkem byla původní 12-položková škála, využívající čtyřbodovou Likertovu škálu (určitě souhlasím-souhlasím-nesouhlasím-určitě nesouhlasím). Autoři původně vycházeli z predpokladu, že je možné vytvořit nástroj s jedinou dimenzí, rozlišující antropocentrický pohled na svět jako zdroj surovin (dominantní sociální paradigma) a neantropocentrický pohled chápající svět jako ohrožený lidskou činností (nové sociální paradigma) (Dunlap, 2008). V roce 2000 pak Dunlap et al. (2000) publikovali novou, revidovanou 15-položkovou škálu ${ }^{3}$, u které doložili reliabilitu Cronbach alfa $=0,83$.

NEP byl od počátku svého vzniku používán i kritizován. LaLonde a Jackson (2002) považují nástroj za príliiš zjednodušující a zastaralý. Některé položky jsou podle nich zavádějící a mohou vést ke špatné interpretaci výsledků. ${ }^{4}$ Podobné výhrady uvádí i LaTrobe a Acott (2000), podle kterých ve dnešní době už většina lidí zastává názory odpovídající novému ekologickému paradigmatu. Vymezení obou pólů NEP/DSP kritizuje také Lundmark (2007). Podle jejího názoru NEP dobře odráží antropocentrické postoje, zatímco stanoviska odpovídající „ekologickému myšleni“ odpovídají spiše „mělké“ ekologii a nereflektují současnou diskusi o environmentální etice. Napřiklad přesvědčení, že lidé jsou závislí na př́rodních zákonech, podle jejího názoru neodráží ekologické myšlení, ale pouhou znalost vědeckého faktu.

Další diskuse probíhají o počtu dimenzí NEP. Původní NEP předpokládal jednu dimenzi rozlišující NEP a DSP (Dunlap \& van Liere, 1978). Revidovaný NEP oproti tomu rozlišuje pět dimenzí, které v něm mohou být zvlášt́ vyhodnocovány (Dunlap et al., 2000, Dunlap, 2008). Ani zde není diskuse jednoznačná. Dunlap $(2000,2008)$ doporučuje používat novou verzi nástroje a rozlišovat jednotlivé dimenze.

Těmi jsou (Dunlap et al., 2000, Amburgey \& Thoman, 2012):

- rovnováha př́rody (přesvědčení, že lidské aktivity ovlivňují rovnováhu př́rody) (box č. 1, p. 1-3);

- ekologická krize (přesvědčení, že lidé závažně poškozuji životní prostředí) (box č. 1, p. 4-6);

- ne-výjimečnost (přesvědčení, že lidské bytosti nejsou výjimkou z př́rodních zákonů) (box č. 1, p. 7-9);

- meze růstu (přesvědčení, že Země má omezené zdroje) (box č. 1, p. 10-12)

- lidská dominance (přesvědčení, že lidé mají právo měnit a řídit prírodní prostředí) (box č. 1, p. 13-15).

\footnotetext{
${ }^{2}$ Nástroj se v pưvodní verzi jmenoval „nové environmentální paradigma“ a byl později přejmenován.

${ }^{3}$ Existuje i zkrácená, šesti-položková verze.

${ }^{4}$ Je třeba uvést, že Dunlap (2008) zpochybnil metodologii jejich výzkumu, který se podle něj zaměřil na nadprůměrně vzdělané respondenty a neodráží proto postoje běžné veřejnosti.
} 
Pracovat s NEP raději jako s pěti podškálami než jedinou doporučují také Amburgey a Thoman (2012). Oproti tomu Cordano et al. (2003) uvádí, že v některých případech může být oprávněné používat původní 12položkovou verzi či zkrácenou 5-položkovou verzi a kombinovat ji s jiným nástrojem.

Poslední důležitou otázkou je, do jaké míry je NEP použitelný v jiných kulturních regionech. Ani zde neexistuje úplná shoda, protože zatímco někteří výzkumníci dokládali nižší konzistenci nástroje ve východní Evropě či Asii, jiní naopak tento problém nezaznamenali (Dunlap, 2008, Vikan et al., 2007, Pe'er et al., 2007, Tuncer, 2009).

Zkušenosti z českého prostředí nejsou jednoznačné. Nástroj byl zpravidla použitý v upravených podobách (srv. Soukup, 2001, Franěk, 2006), případně byl použit pro jiné věkové skupiny (Činčera \& Štěpánek, 2007, Činčera \& Bezouška, 2007, Schovajsová, 2010) a není proto jednoduché vyhodnotit relevanci jeho jednotlivých verzí.

Příkladem upraveného nástroje je i 12-položková verze NEP byla využita při výzkumu učitelů účastnících se specializačního studia pro koordinátory environmentální výchovy, organizovaného v letech 2010-2012 středisky SSEV Pavučina. Východiskem byla revidovaná 15-položková verze NEP, ze které ale byly v průběhu ověřování vyjmuty tři položky. $V$ boxu č. 1 uvádíme použitou variantu nástroje. Vynechané položky jsou uvedeny kurzívou, původní pořadí položky podle revidovaného NEP uvádíme v závorce za položkou. Pro výzkum na 173 respondentech před programem byla použita sedmibodová Likertova škála. ${ }^{5}$

Box č. 1 Nové ekologické paradigma (NEP) (15-položková verze) (Dunlap et al., 2000)

1. Lidské zásahy do př́rody vedou často ke katastrofálním následkům. (3)

2. Rovnováha v prírodě je velmi citlivá a může být snadno narušena. (13)

3. Rovnováha v přirodě je dostatečně stabilní na to, aby se vypořádala s dopady moderní průmyslové společnosti. (8)

4. Lidé závažně poškozují životní prostředí. (5)

5. Takzvaná „ekologická krize“, které lidstvo čelí, se podstatně zveličuje. (10)

6. Budeme-li pokračovat dál stejně jako dosud, brzy budeme čelit závažné ekologické katastrofě. (15)

7. Lidská vynalézavost zajistí, že Země zůstane vždy obyvatelná. (4)

8. Navzdory všem naším schopnostem jsme stále podřízeni zákonům prírody. (9)

9. Lidé se časem naučí dost o fungování přírody na to, aby ji dokázali ovládat. (14)

10. Země je podobná kosmické lodi, která má velmi omezený prostor a zdroje. (11)

11. Bližíme se k limitnímu počtu lidí, které Země dokáže uživit. (1)

12. Země má dostatek prírodních zdrojů, jen se je musíme naučit používat. (6)

13. Zviŕata a rostliny mají stejné právo žít, jako lidé. (7)

14. Lidé mají právo upravovat přírodní prostředí podle svých potřeb. (2)

15. Lidé byli předurčeni $k$ tomu, aby vládli zbytku prírody. (12)

Reliabilita nástroje ale byla poměrně nízká (Cronbach alfa=0,63), analyzováno po dílčích faktorech: rovnováha přírody (alfa=0,46), ekologická krize (alfa=0,42), ne-výjimečnost (alfa=0,33), další faktory nebyly kvůli krácení hodnoceny. To mohlo být způsobeno několika faktory. Revidovaný NEP (Dunlap et al., 2000) pracoval s pětibodovou Likertovou škálou, prezentovaný výzkum se sedmibodovou. Revidovaný NEP řadí jinak položky, aby za sebou nenásledovaly ty, které patří do stejné dimenze. Z nástroje byly tři položky vyňaty. Konečně, je možné, že nástroj by nebyl pro danou skupinu respondentů vhodný ani v neupravené podobě. ${ }^{6}$

\footnotetext{
${ }^{5}$ Položky, které jsou formulovány z pohledu DSP, je při zpracování třeba invertovat, tj. souhlasné vyjádření hodnotit nejméně body.

${ }^{6}$ Opakované problémy s nízkou reliabilitou „kvazi-NEP škály“ uvádí také Soukup (2001), při výzkumu v roce 2000 Cronbach alfa=0,54.
} 
I přes uvedené výhrady je možné říct, že žádný jiný nástroj na měření environmentálních postojů neprošel tak dlouhou diskusí a nebyl tak rozsáhle používán, jako NEP. Pro potřeby výzkumu environmentálních postojů určité cílové skupiny je nicméně na místě zvážit jeho nahrazení či doplnění jiným nástrojem.

Více nástrojů bylo sestaveno pro měření propojení s přírodou. Jedním z nich je Connected to Nature Scale (CNS), který sestavili Mayer a Frantz (2004). Nástroj existuje ve více verzích. Původní verze je 14 položková (v. box č. 2). Byla ověřována na několika skupinách respondentů (Cronbach alfa $=0,84$ ) a následně v upravené 13 položkové verzi ve výzkumu Mayer et al. (2009).

Alternativou k CNS je nástroj Nature Relatedness (NR), vyvinutý Nisbetem a kol. (2009). Nástroj se skládá ze tří subškál: NR self, která se zaměřuje na vnitřní identifikaci s př́rodou (box č. 3, položky 1-9), NR perspektivta, která popisuje pohled na lidskou činnost a její vliv na živé věci (box č. 3, položky 10-15) a NR prožitky, která odráží fyzickou blízkost s přírodním světem, požadovaný komfort v přírodě a fascinaci přírodním světem (box č. 3, položky 16-21). Ověřený český překlad publikoval Franěk (2012) (v. box č. 3). Podle něj je nástroj možné „s jistými výhradami užívat při testování emocionálního, kognitivního či zážitkového spojení s přírodou." Nástroj byl v českém prostředí testován na množině 357 studentů vysokých škol. Český překlad měl velmi dobrou reliabilitu jako celek (Cronbachovo alfa=0,87), subškála NR perspektiva však prokázala reliabilitu pouze alfa=0,66. Není zřejmé, zda nižší reliabilita odráží chyby v překladu nebo je kulturně specifická.

Box č. 2 Connected to Nature Scale (CNS) (14-ti položková verze) (Mayer a Frantz, 2004)

1. Často cítím pocit jednoty s prírodním světem kolem sebe.

2. Vnímám přirodní svět jako společenství, do kterého patřím.

3. Uvědomuji si a oceňuji inteligenci ostatních živých organizmů.

4. Často se cítím odpojený od prírody.

5. Když přemýšlím o svém životě, představuji sám sebe jako součást většího koloběhu života.

6. Často cítím pocit spříznění se zvířaty a rostlinami.

7. Připadám si, jako kdybych patřil k Zemi tak, jako Země patří ke mně.

8. Hluboce si uvědomuji, jak moje jednání ovlivňuje přírodní svět.

9. Často se cítím jako část pavučiny života.

10. Cítím, že všichni obyvatelé Země, at již lidští či ne-lidští, sdílí společnou „životní sílu“.

11. Tak jako je strom součástí lesa, i já si připadám zahrnutý do širšího, přírodního světa.

12. Když přemýšlím o svém místě na Zemi, cítím se být součástí nejvyšší úrovně hierarchie, která v přírodě existuje.

13. Často se cítím tak, jako bych byl jen malou částí přírodního světa kolem sebe, a to, co jsem, není důležitější, než tráva na zemi či ptáci na stromech.

14. Můj osobní blahobyt nesouvisí s na blahobytu přírodního světa. 
Box č. 3 Nature relatedness (NR) (česká verze) (Franěk, 2012)

1. Vždy myslím na to, jak mé chování může ovlivnit životní prostředí.

2. Mé spojení s prírodou a prírodním prostředím je součástí mého duchovního života.

3. Plně si uvědomuji problémy ohrožení životního prostředí.

4. Nejsem oddělen od prírody, ale jsem její součástí.

5. Můj vztah k prrírodě nemá vliv na to, jak žiji v každodenním životě.

6. I uprostřed města si všímám přírodních prvků.

7. Můj vztah k přírodě je důležitou částí mé vlastní osobnosti.

8. Uvažuji hodně o utrpení zvířat.

9. Cítím, že jsem silně spojený/á se všemi živými tvory na zemi.

10. Některé živočišné a rostlinné druhy prostě musí vyhynout.

11. Lidé mají právo využívat přírodní zdroje zcela libovolným způsobem.

12. To, co dělám, nemůže ovlivnit ekologické problémy v jiných místech planety.

13. Zvírata, ptáci a rostliny nemohou mít stejná práva, jako mají lidé.

14. Ochrana přírody není nezbytná, protože příroda sama je natolik silná, že se dokáže vzpamatovat z lidských zásahů.

15. Současný stav př́rodních druhů ukazuje, jak to $v$ budoucnu dopadne s lidstvem.

16. Chodím rád/a venku, i když zrovna není př́ijemné počasí.

17. Ideální místo pro prázdniny nebo dovolenou by pro mě bylo někde v odlehlé divoké prírodě.

18. Baví mě rýpat se v zemi a vůbec mi nevadí, že si při tom ušpiním ruce.

19. Všímám si volně žijících zviŕat, at' jsem kdekoli.

20. Nenavštěvuji často prírodu.

21. Představa, že jsem v hlubokých lesích pryč od civilizace, je pro mě velmi děsivá.

Položky, které jsou v obou nástrojích formulovány „obráceně“, je při zpracování vždy třeba invertovat, tj. hodnotit opačně.

Posledním nástrojem měřícím propojení s přírodou, který zde uvedeme, je Inclusion of Nature in Self (INS), který pro studii provedenou na 148 vysokoškolských studentech adaptoval Schultz (2001). Nástroj se skládá z jediné položky a dosud u nás nebyl ověřován (box č. 4).

Box č. 4 Inclusion of Nature in Self (INS) (Schultz, 2001)

Zakroužkujte prosím jeden z obrázků, který nejlépe popisuje váš vztah s přírodou. Jak jste s př́rodou propojeni?
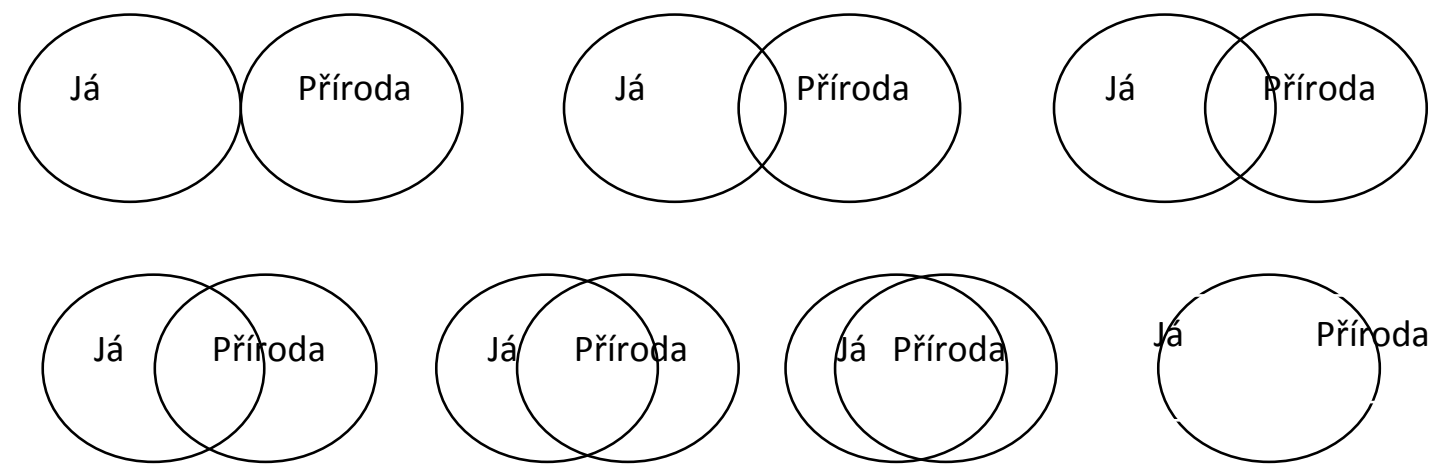


\section{VZTAH K MÍSTU}

Cíle a indikátory EVVO (Broukalová a kol., 2012) uvádí pro tuto oblast dva rámcové cíle (v. tab. č. 3). V tab. č. 4 opět uvádíme příklady souvisejících proměnných.

Tab. č. 3 Vztah k místu v Cílech a indikátorech EVVO

\begin{tabular}{|c|c|c|}
\hline Rámcový cíl & $\begin{array}{l}\text { Vysvětlující komentář (je nutno brát } \\
\text { jako pouze ilustrativní a indikativní } \\
\text { výklad) }\end{array}$ & $\begin{array}{l}\text { Orientační příklady možností ověření, } \\
\text { popř. indikátorů (co je například možné } \\
\text { vyhodnocovat a jakým nástrojem) }\end{array}$ \\
\hline $\begin{array}{l}\text { Znalost místa, jeho } \\
\text { jedinečnosti a schopnost } \\
\text { interpretovat jej } \\
\text { v souvislostech }\end{array}$ & $\begin{array}{l}\text { - Schopnost popsat čím je určité } \\
\text { místo jedinečné, jak v něm funguje } \\
\text { propojení společnost-příroda, jak se } \\
\text { místo proměňovalo v závislosti na } \\
\text { různých faktorech, jaké jsou citlivé } \\
\text { složky prostředí v místě, jak se místo } \\
\text { odráží v kultuře, příbězích apod. }\end{array}$ & $\begin{array}{l}\text { - Znalost významných míst v krajině, } \\
\text { místních príběhů (test, portfolio, } \\
\text { rozhovor). } \\
\text { - Úroveň percepce (místní) krajiny } \\
\text { (mentální mapy, rozhovor, esej). }\end{array}$ \\
\hline $\begin{array}{l}\text { Vědomí sounáležitosti } \\
\text { s místem a regionem a } \\
\text { pocit zodpovědnosti za } \\
\text { něj }\end{array}$ & $\begin{array}{l}\text { - Schopnost popsat, proč je pro mě } \\
\text { dané místo důležité, jaké lokality } \\
\text { v něm mám rád, co se mi v něm } \\
\text { líbí/nelíbí, co pro místo můžu } \\
\text { udělat, jaké vnímám problémy } \\
\text { místa. }\end{array}$ & $\begin{array}{l}\text { - Ochota trávit v lokalitě volný čas } \\
\text { (dotazník) } \\
\text { - Vztah k místu (dotazník, rozhovor, } \\
\text { esej, volný text, obrazová reflexe). } \\
\text { - Ochota zapojit se do akcí na ochranu } \\
\text { či zkrášlování lokality (dotazník, } \\
\text { sledování účasti na akcích). }\end{array}$ \\
\hline
\end{tabular}

Tab. č. 4Proměnné pro Vztah k místu

\begin{tabular}{|c|c|c|}
\hline Rámcový cíl & Příklady proměnných & Definice proměnných \\
\hline $\begin{array}{l}\text { Znalost místa, } \\
\text { jeho jedinečnosti } \\
\text { a schopnost } \\
\text { interpretovat jej } \\
\text { v souvislostech }\end{array}$ & Znalost vybraných lokalit v krajině & $\begin{array}{l}\text { Znalost konkrétních míst a schopnost je rámcově } \\
\text { geograficky zařadit. }\end{array}$ \\
\hline & Interpretace místa & $\begin{array}{l}\text { Schopnost interpretovat specifické př́rodní či } \\
\text { sociální významové roviny určité lokality. }\end{array}$ \\
\hline & Hodnocení místa & $\begin{array}{l}\text { Schopnost zaujmout pozitivní, negativní či neutrální } \\
\text { stanovisko k různým aspektům krajiny. }\end{array}$ \\
\hline \multirow[t]{2}{*}{$\begin{array}{l}\text { Vědomí } \\
\text { sounáležitosti } \\
\text { s místem a } \\
\text { regionem a pocit } \\
\text { zodpovědnosti za } \\
\text { něj }\end{array}$} & Smysl místa (sense of place) & $\begin{array}{l}\text { Respondentem reflektované propojení s určitým } \\
\text { místem na biofyzikální, psychologické, sociokulturní } \\
\text { a politicko-ekonomické rovině } \\
\text { Zpravidla obsahuje dvě či více dimenzí, jako je vazba } \\
\text { k místu a význam místa }\end{array}$ \\
\hline & $\begin{array}{l}\text { Vazba k místu } \\
\text { (place } \\
\text { attachment) }\end{array}$ & $\begin{array}{l}\text { Pocitované pouto mezi respondentem a konkrétním } \\
\text { místem } \\
V \text { rámci proměnné se někdy rozlišují další dimenze, }\end{array}$ \\
\hline
\end{tabular}




\begin{tabular}{|c|c|c|c|}
\hline & & & $\begin{array}{l}\text { jako je závislost na místě (place dependence) a } \\
\text { identita místa (place identity): } \\
\text { Závislost na místě = potenciál místa k naplnění } \\
\text { individuálních potřeb poskytnutím prostředí pro } \\
\text { respondentem preferované aktivity. } \\
\text { ldentita místa = míra, s jakou respondent chápe } \\
\text { místo jako součást své identity nebo jej zahrnuje do } \\
\text { svého sebepojetí. }\end{array}$ \\
\hline & & $\begin{array}{l}\text { Význam místa } \\
\text { (place meaning) }\end{array}$ & $\begin{array}{l}\text { Symbolický význam pripisovaný místu } \\
\text { respondentem }\end{array}$ \\
\hline & \multicolumn{2}{|l|}{ Atraktivita místa } & $\begin{array}{l}\text { Intenzita zájmu respondenta o návštěvu určité } \\
\text { lokality. }\end{array}$ \\
\hline & \multicolumn{2}{|c|}{ Odpovědné chování k místu } & $\begin{array}{l}\text { Ochota zapojit se do akcí na ochranu místa; } \\
\text { preference odpovědných variant chování ve vztahu } \\
\text { k místu. }\end{array}$ \\
\hline
\end{tabular}

Proměnné související se vztahem k místu byly v zahraničí měřeny v řadě výzkumů (Kyle et al., 2005, Casakin \& Billig, 2009, Ardoin et al., 2012, Kudryvtsev et al., 2012). V České republice bohužel dosud chybí domácí adaptace vhodného nástroje.

Jako příklad místně specifického nástroje můžeme použít dotazník, který připravili Kyle et al. (2005) pro výzkum na návštěvnících Apalačské stezky. Nástroj měří tři proměnné: identitu místa (box č. 5, p. 1-4), závislost na místě (box č. 5, p. 5-8) a sociální vazbu k místu7 (box č. 5, p. 9-12).

Box č. 5 Vztah k místu (Apalačské stezce) (Kyle et al., 2005)

1. Tato stezka pro mě hodně znamená.

2. Jsem k Apalačské stezce hodně připoutaný.

3. Silně se s touto stezkou identifikuji.

4. Necítím k této stezce žádný závazek.

5. Chodím po Apalačské stezce raději, než po jakékoliv jiné.

6. Když navštívím tuto stezku, cítím se spokojenější, než kdybych navštívil jakoukoliv jinou.

7. Chození po této stezce je pro mě důležitější, než chození po jakékoliv jiné stezce.

8. Nikdy bych ten typ rekreace, který dělám tady, nenahradil za jiný.

9. Mám mnoho vzpomínek na Apalačskou stezku.

10. O této stezce moc lidem nevyprávím.

11. Na toto místo jednou přivedu svoje děti.

Před případnou adaptací do českého prostředí je třeba varovat před použitím záporů v položkách. Nástroj by se pravděpodobně mohl stát východiskem pro sestavení původního dotazníku, je ale zřejmé, že použití musí předcházet další ověřování.

\footnotetext{
${ }^{7}$ Autoři chápou sociální vazbu jako sociální dimenzi vazby k místu (place attachment).
} 


\section{EKOLOGICKÉ DĚJE A ZÁKONITOSTI}

Proměnné, související s porozuměním ekologickým dějům a zákonitostem, nebývají přiliš často u dospělé populace měřeny. Př́padné výzkumy se často soustředí na učitele či studenty učitelství (Pe'er et al., 2007, Hsu \& Roth, 1998, Tuncer, 2009, Dvořáčková \& Ryplová, 2012), méně často i na širokou veřejnost (Morrone et al., 2001). Příklad jejich vymezení pro rámcové cíle z dokumentu Cíle a indikátory EVVO (v. tab. č. 5) uvádí tab. č. 6 :

Tab. č. 5 Ekologické děje a zákonitosti v Cílech a indikátorech EVVO

\begin{tabular}{|c|c|c|}
\hline Rámcový cíl & $\begin{array}{l}\text { Vysvětlující komentář (je nutno brát } \\
\text { jako pouze ilustrativní a indikativní } \\
\text { výklad) }\end{array}$ & $\begin{array}{l}\text { Orientační přílady možností ověření, } \\
\text { popř. indikátorů (co je například možné } \\
\text { vyhodnocovat a jakým nástrojem) }\end{array}$ \\
\hline $\begin{array}{l}\text { Zájem o pochopení } \\
\text { ekologických dějů a } \\
\text { jejich zkoumání }\end{array}$ & $\begin{array}{l}\text { - Vědomí potřebnosti vědeckého } \\
\text { zkoumání ekologických jevů. } \\
\text { - Uvědomění si nejistot v poznání } \\
\text { ekologických dějů } \\
\text { - Vlastní zkušenost se zkoumáním } \\
\text { ekologických dějů a její reflexe. }\end{array}$ & 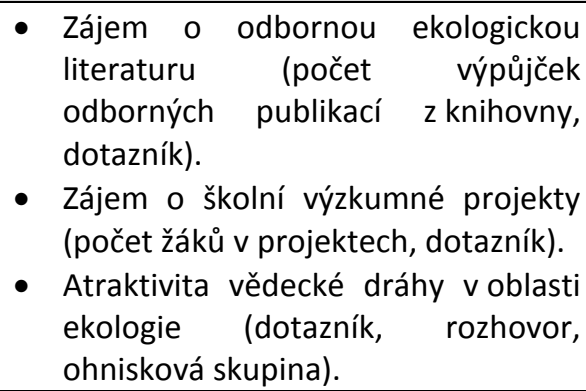 \\
\hline $\begin{array}{l}\text { Schopnosti a dovednosti } \\
\text { pro zkoumání přírody a } \\
\text { životního prostředí }\end{array}$ & $\begin{array}{l}\text { - Porozumění principům zkoumání } \\
\text { prírody. } \\
\text { - Schopnost kritické analýzy informací } \\
\text { o životním prostředí, formulování } \\
\text { otázek, navrhování postupu } \\
\text { výzkumu, sběr dat, vyhodnocení a } \\
\text { interpretace získaných údajů. }\end{array}$ & $\begin{array}{l}\text { - Schopnost zvládnout jednotlivé fáze } \\
\text { vědeckého postupu (portfolio, } \\
\text { pozorování, dovednostní test). }\end{array}$ \\
\hline $\begin{array}{l}\text { Porozumění základním } \\
\text { ekologickým dějům a } \\
\text { zákonitostem }\end{array}$ & $\begin{array}{l}\text { - Osvojení základních termínů } \\
\text { (ekosystém, biodiverzita, ekologická } \\
\text { stabilita, apod.), pochopení } \\
\text { základních procesů (toků energie, } \\
\text { vodního cyklu, koloběhu látek, } \\
\text { vztahů mezi organismy a jejich } \\
\text { prostředím), vývoji populací a } \\
\text { společenstev, apod. }\end{array}$ & $\begin{array}{l}\text { - Porozumění základním pojmům a } \\
\text { odbornému textu (znalostní test). } \\
\text { - Schopnost aplikace principů na } \\
\text { konkrétní jevy (test). }\end{array}$ \\
\hline 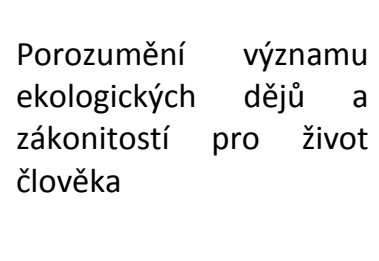 & 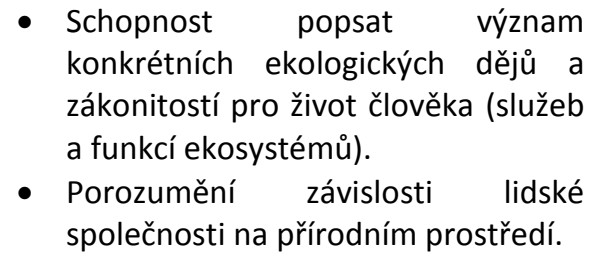 & $\begin{array}{l}\text { - Porozumění provázanosti mezi } \\
\text { člověkem a prírodou (esej, volný } \\
\text { text, znalostní test, rozhovor). }\end{array}$ \\
\hline $\begin{array}{l}\text { Propojování znalostí } \\
\text { ekologických dějů a } \\
\text { zákonitostí } \\
\text { s každodenním životem }\end{array}$ & $\begin{array}{l}\text { - Schopnost aplikovat ekologické děje } \\
\text { a zákonitosti na přímou životní } \\
\text { zkušenost. }\end{array}$ & $\begin{array}{l}\text { - Schopnost identifikovat dopady } \\
\text { svého chování na životní prostředí } \\
\text { (rozhovor, znalostní test). } \\
\text { - Využití znalostí ekologických dějů } \\
\text { v modelových životních situacích } \\
\text { (projekce, test). }\end{array}$ \\
\hline
\end{tabular}


Tab. č. 6 Proměnné pro Ekologické děje a zákonitosti

\begin{tabular}{|c|c|c|}
\hline Rámcový cíl & Příklady proměnných & Definice proměnných \\
\hline $\begin{array}{l}\text { Zájem o pochopení } \\
\text { ekologických dějů a } \\
\text { jejich zkoumání }\end{array}$ & Atraktivita ekologie & $\begin{array}{l}\text { Intenzita zájmu respondenta o aktivity související } \\
\text { s ekologickým výzkumem př́rody. }\end{array}$ \\
\hline $\begin{array}{l}\text { Schopnosti a dovednosti } \\
\text { pro zkoumání přírody a } \\
\text { životního prostředí }\end{array}$ & Badatelské dovednosti & $\begin{array}{l}\text { Porozumění badatelskému cyklu a osvojení } \\
\text { dovedností pro jeho jednotlivé fáze, např. formulace } \\
\text { výzkumné otázky, hypotéz, príprava výzkumu, sběr } \\
\text { dat v terénu, vyhodnocení, interpretace a prezentace } \\
\text { dat. }\end{array}$ \\
\hline $\begin{array}{l}\text { Porozumění základním } \\
\text { ekologickým dějům a } \\
\text { zákonitostem }\end{array}$ & $\begin{array}{l}\text { Porozumění ekologickým } \\
\text { konceptům }\end{array}$ & $\begin{array}{l}\text { Schopnost vlastními slovy vysvětlit a na konkrétních } \\
\text { příkladech doložit vybrané koncepty fungování } \\
\text { přírody, např. cykly, provázanost, změna, potravní } \\
\text { řetězec atd. }\end{array}$ \\
\hline 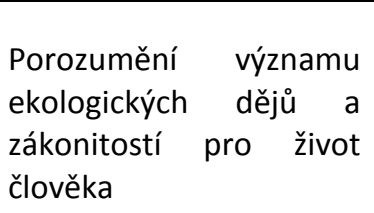 & $\begin{array}{l}\text { Porozumění eko-sociální } \\
\text { provázanosti }\end{array}$ & $\begin{array}{l}\text { Schopnost na konkrétních př́kladech propojit vybraný } \\
\text { ekologický koncept a potřeby lidské společnosti. }\end{array}$ \\
\hline $\begin{array}{l}\text { Propojování znalostí } \\
\text { ekologických dějů a } \\
\text { zákonitostí } \\
\text { s každodenním životem }\end{array}$ & $\begin{array}{l}\text { Porozumění ekologické } \\
\text { provázanosti }\end{array}$ & $\begin{array}{l}\text { Schopnost na konkrétních příkladech propojit vybraný } \\
\text { ekologický koncept s vlastním chováním. }\end{array}$ \\
\hline
\end{tabular}

Hsu a Roth (1998) pomocí dvou položek zkoumali v rámci většího výzkumu environmentální gramotnosti tchajwanských středoškolských učitelů míru jejich přesvědčení o znalostech z ekologie a environmentalistiky (př́iklad položky v. box č. 6).

V České republice se ekologickými znalostmi studentů učitelství zabývali Dvořáčková a Ryplová (2012). Ve výzkumu environmentální gramotnosti studentů učitelství tyto znalosti měřili pomocí tří otevřených otázek, které pak následně bodovaly (v. box č. 6).

Box č. 6 Příklady položek na měření ekologických znalostí

- Do jaké míry byste řekli, že rozumíte ekologické problematice (např. pojmům, jako je ekosystém, potravní řetězec, toky energie, sukcese, populace a komunita)? (Hsu a Roth, 1998)

- Vypište co nejvíc príkladů vztahů mezi rostlinami a atmosférou: (Dvořáčková a Ryplová, 2012)

- C Čím vším může člověk urychlit erozi hornin? (Dvořáčková a Ryplová, 2012)

Propracovaný nástroj na měření ekologických znalostí široké veřejnosti v Ohio připravili Morrone et al. (2001). Pro svůj výzkum nadefinovali osm základních ekologických principů: biogeografie, Země jako biosféra, ekologická energetika, únosná kapacita, ekologická sukcese, biotická interakce, biodiverzita a koloběh 
materiálů (ukázka v. box č. 7). Reliabilita byla vyhodnocována z kumulativního skóre položek pro každý z osmi principů (Cronbach alfa=0,65).

Box č. 7 Ukázka z testu ekologických znalostí (Morrone et al., 2001)

Koloběh materiálů

PCB, toxická chemikálie, může být nalezena ve spodních vodách Velkých jezer. PCB zde vstřebávají korýši, kteří žijí ve vodě. Kdo bude mít v těle nejvyšší hladinu PCB?

a) Korýši

b) Ryby, které jedí korýše

c) Ptáci, kteří jedí ryby

Fosforečnatá hnojiva se dávají na trávníky, zahrady i pole, aby podpořily růst rostlin. Co se stane, když se fosforečnany smyjí do jezera?

a) Fosforečnany zabijí ryby

b) Fosforečnany zvýší množství řas

c) Nic moc se nestane

Dusíkatá hnojiva se používají na zahrady a pole pro zvýšení produkce obilí. Dusík se dostává do jídla. Když člověk sní potravu, aby měl energii a mohl růst, produkuje kanalizační odpad. Lidské výkaly obsahují některé dusičnany, které byly před tím použity jako hnojivo.

pravda/nepravda

V České republice je př́prava nástrojů na měření těchto proměnných pro dospělou klientelu stále v počátcích. Nedostatek relevantních nástrojů patrně odráží i to, že v České republice není dosud konsensus ohledně toho, jaké ekologické znalosti by studenti učitelství a učitelé měli mít.

V počátcích je také tvorba domácích nástrojů pro vyhodnocování badatelských dovedností studentů učitelství. Lze předpokládat, že některé postupy prezentované v metodice pro žáky druhého a třetího stupně, by bylo možné použít i zde. Dvořáčková a Ryplová (2012) prezentovali ve svém výzkumu jednopoložkový nástroj měřící porozumění principům vědecké práce (v. box č. 8).

Box č. 8 Porozumění principům vědecké práce (Dvořáčková a Ryplová, 2012)

Plánujete pokus pro děti z př́rodovědného kroužku. Očíslujte podle správného pořadí jednotlivé etapy průběhu pokusu:

- Konfrontace vlastních zjištění se zjištěními ostatních

- Získávání a trídění informací o problému

- Vyhledání informačních zdrojů ke zkoumané problematice

- Formulace hypotézy

- Vyvození závěrů

- Sestavení metodiky pokusu

- Testování hypotézy

- Aplikace zjištěných závěrů do praktického života

- Potvrzení nebo vyvrácení hypotézy 
Evaluátorům, kteří by chtěli u dospělé evaluace hodnotit stav ekologických znalostí, Ize doporučit zaměřit se bud' na užší proměnné (např. porozumění koloběhu materiálů), nebo nejprve pečlivě nadefinovat koncepty, které by test měl měřit. 


\section{ENVIRONMENTÁLNÍ PROBLÉMY A KONFLIKTY}

Proměnné, související s rámcovými cíli vymezenými pro Environmentální problémy a konflikty (v. tab. č. 7) (Broukalová a kol., 2012), uvádí tab. č. 8:

Tab. č. 7 Environmentální problémy a konflikty v Cílech a indikátorech EVVO

\begin{tabular}{|c|c|c|}
\hline Rámcový cíl & $\begin{array}{l}\text { Vysvětlující komentář (je nutno brát } \\
\text { jako pouze ilustrativní a indikativní } \\
\text { výklad) }\end{array}$ & $\begin{array}{l}\text { Orientační př́klady možností ověření, } \\
\text { popř. indikátorů } \\
\text { (co je například možné vyhodnocovat a } \\
\text { jakým nástrojem) }\end{array}$ \\
\hline $\begin{array}{l}\text { Schopnost analýzy } \\
\text { environmentálních } \\
\text { problémů a konfliktů }^{8}\end{array}$ & $\begin{array}{l}\text { - Schopnost vyhledávat a srovnávat } \\
\text { informace o problému a konfliktu } \\
\text { z různých zdrojů, kriticky je zkoumat } \\
\text { a posuzovat. } \\
\text { - Schopnost zkoumat příčiny, } \\
\text { následky, ekonomické, sociální a } \\
\text { historické souvislosti problémů a } \\
\text { konfliktů. } \\
\text { - Schopnost identifikovat názorové } \\
\text { strany konfliktu a analyzovat } \\
\text { hodnoty, přesvědčení a záměry, se } \\
\text { kterými jednotlivé strany do } \\
\text { konfliktu vstupují. }\end{array}$ & $\begin{array}{l}\text { - Znalost vybraných místních i } \\
\text { globálních environmentálních } \\
\text { problémů, jejich přičin, mechanismů } \\
\text { fungování, důsledkům a možným } \\
\text { řešením (znalostní test, rozhovor, } \\
\text { ohnisková skupina, esej, volný text, } \\
\text { portfolio). } \\
\text { - Postoj k závažnosti a možným } \\
\text { rešením problému (dotazník, } \\
\text { rozhovor). identifikovat v textu } \\
\text { - Schopnost kétive } \\
\text { environmentální konflikt, jednotlivé } \\
\text { strany konfliktu a jejich postoje } \\
\text { (dovednostní test). }\end{array}$ \\
\hline $\begin{array}{lc}\text { Schopnost } & \text { formulovat } \\
\text { vlastní názor na } \\
\text { problém, posuzovat } \\
\text { variantní řešení a } \\
\text { navrhovat řešení vlastní }\end{array}$ & $\begin{array}{l}\text { - Schopnost porovnávat různé návrhy } \\
\text { na řešení problému a odhadovat } \\
\text { důsledky navržených řešení. } \\
\text { - Schopnost posoudit přijatelnost } \\
\text { navrženého řešení pro různé } \\
\text { názorové strany konfliktu. }\end{array}$ & $\begin{array}{l}\text { - Schopnost zvážit jednotlivé varianty } \\
\text { a navrhnout alternativní rešení } \\
\text { environmentálního konfliktu (esej, } \\
\text { rozhovor, ohnisková skupina, } \\
\text { hodnocení žákovských projektů). }\end{array}$ \\
\hline $\begin{array}{l}\text { Schopnost spolupráce a } \\
\text { komunikace při řešení } \\
\text { environmentálních } \\
\text { konfliktů }\end{array}$ & $\begin{array}{l}\text { - Porozumění významu komunikace a } \\
\text { spolupráce při řešení konfliktů a } \\
\text { důsledkům vznikajícím při odmítání } \\
\text { či porušování těchto principů. } \\
\text { - Dovednost účastnit se a vést diskusi. } \\
\text { - Schopnost hledat a identifikovat } \\
\text { řešení problému, která vycházejí } \\
\text { z principů spolupráce a jsou } \\
\text { přijatelná různými stranami } \\
\text { konfliktu. }\end{array}$ & $\begin{array}{l}\text { - Schopnost vést dialog, metody } \\
\text { rozhodování, ochota zapojit se do } \\
\text { diskuse a rešení (strukturované } \\
\text { pozorování, rozhovory). }\end{array}$ \\
\hline
\end{tabular}

\footnotetext{
${ }^{8}$ Problém vzniká v situaci, kdy je ohrožena určitá složka životního prostředí. Konflikty vznikají tehdy, pokud je více názorů na řešení problému.
} 
Tab. č. 8 Proměnné pro Environmentální problémy a konflikty

\begin{tabular}{|c|c|c|}
\hline Rámcový cíl & Příklady proměnných & Definice proměnných \\
\hline \multirow[t]{5}{*}{$\begin{array}{l}\text { Schopnost analýzy } \\
\text { environmentálních } \\
\text { problémů a konfliktů }\end{array}$} & $\begin{array}{l}\text { Environmentální vědomí } \\
\text { (environmental } \\
\text { awareness) }\end{array}$ & $\begin{array}{l}\text { Znalost environmentálních problémů na globální, } \\
\text { národní i regionální úrovni, schopnost pojmenovat } \\
\text { př́činy i důsledky vyplývající z jejich ekologické, } \\
\text { sociální a ekonomické provázanosti a znalost } \\
\text { základních strategií jejich řešení. }\end{array}$ \\
\hline & $\begin{array}{l}\text { Environmentální zaujetí } \\
\text { (environmental concern) }\end{array}$ & $\begin{array}{l}\text { Závažnost přisuzovaná environmentálním problémům } \\
\text { a ohrožení životního prostřed. }\end{array}$ \\
\hline & $\begin{array}{l}\text { Vnímané riziko } \\
\text { environmentálního } \\
\text { problému (perceived risk) }\end{array}$ & $\begin{array}{l}\text { Míra závažnosti přisuzovaná konkrétnímu problému } \\
\text { respondentem. }\end{array}$ \\
\hline & $\begin{array}{l}\text { Dovednosti pro analýzu } \\
\text { environmentálních } \\
\text { problémů / konfliktů }\end{array}$ & $\begin{array}{l}\text { Schopnost rozlišit environmentální problém a konflikt, } \\
\text { identifikovat problém a konflikt, pojmenovat } \\
\text { zainteresované strany, určit jejich postoje a hodnoty. }\end{array}$ \\
\hline & $\begin{array}{l}\text { Dovednosti pro výzkum } \\
\text { environmentálního } \\
\text { konfliktu. }\end{array}$ & $\begin{array}{l}\text { Schopnost formulovat si výzkumnou otázku, } \\
\text { navrhnout plán výzkumu, sebrat, vyhodnotit a } \\
\text { prezentovat data související s environmentálním } \\
\text { konfliktem. }\end{array}$ \\
\hline \multirow{2}{*}{$\begin{array}{l}\text { Schopnost formulovat } \\
\text { vlastní názor na } \\
\text { problém, posuzovat } \\
\text { variantní řešení a } \\
\text { navrhovat řešení vlastní }\end{array}$} & $\begin{array}{l}\text { Postoj ke konkrétnímu } \\
\text { environmentálnímu } \\
\text { problému / konfliktu }\end{array}$ & $\begin{array}{l}\text { Názor respondenta na závažnost konkrétního } \\
\text { problému / konfliktu a důležitost jeho řešení. }\end{array}$ \\
\hline & 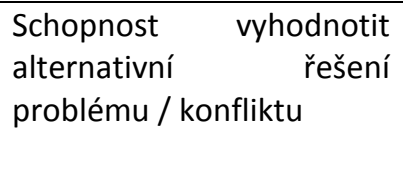 & $\begin{array}{l}\text { Pozitivní, negativní či neutrální stanovisko } \\
\text { respondenta na jednotlivá alternativní řešení určitého } \\
\text { problému / konfliktu. }\end{array}$ \\
\hline \multirow{2}{*}{$\begin{array}{l}\text { Schopnost spolupráce a } \\
\text { komunikace při řešení } \\
\text { environmentálních } \\
\text { konfliktů }\end{array}$} & Zapojení do spolupráce & $\begin{array}{l}\text { Míra zapojení respondenta do činnosti skupiny, } \\
\text { spokojenost respondenta se zapojením. }\end{array}$ \\
\hline & $\begin{array}{l}\text { Kvalita komunikace ve } \\
\text { skupině }\end{array}$ & Převládající komunikační mechanismy ve skupině. \\
\hline
\end{tabular}

Situace ohledně nástrojů na měření proměnných souvisejících s environmentálními problémy a konflikty je analogická. Respondenty jsou opět často studenti učitelství. V testech se většinou objevují dva typy strategií. První se týká míry obecnosti testu, druhá typu použitých položek. Některé testy se zaměřují na obecnější proměnné, tj. např́klad na „environmentální vědomi“, někdy označované jako „environmentální znalosti“. Jejich výhodou je srozumitelná interpretace výsledků. Nevýhodou může být př́lišná výběrovost témat, které 
jsou do testu začleněny, a náročnost zpracování reliabilního testu. Jiné testy se zaměřují na specifičtější proměnné, související s konkrétním environmentálním problémem či konfliktem.

Druhou strategií pak je volba mezi otevřenými a uzavřenými položkami. Otevřené položky jsou pro respondenty náročnější, ale jejich kódování vyžaduje jasně stanovená pravidla a je méně spolehlivé. Uzavřené položky pak zvyšují riziko uhodnutí respondentem, zejména jde-li o položky typu „pravda/nepravda“.

Příklady konkrétněji zaměřených testů najdeme u Boyese et al. (1995) či Dova (1996). Boyes et al. (1995) zkoumali znalosti studentů učitelství o problematice ozonové díry. K výzkumu použili jednoduchý test, skládající se z 36 tvrzení. U každého pak respondenti měli rozhodnout na škále „jsem si jistý, že je to správně“ - „myslím si, že je to správně“ - „nejsem si tím jistý“ - myslím, že to je špatně“ - „jsem si jistý, že to je špatně“ (ukázka z testu v. box č. 9).

Box č. 9 Ukázka z testu znalostí o ozonové díře (Boyes et al., 1995)

Ozonová díra

1. Je vrstva plynů

2. Je okolo Slunce

3. Nachází se uvnitř plechovky spreje

4. Chrání Zemi před UV paprsky (ultra-fialovými paprsky) od Slunce

5. Je na povrchu tekutiny

6. Udržuje svět teplý

Na podobném principu sestavil test znalostí studentů učitelství o změnách klimatu, ozonové díre a kyselých deštích Dove (1996). V rámci testu se studenti vyjadřovali k jednotlivým tvrzením na škále „souhlasímnesouhlasím-nevím“ (v. box č. 10), případně vybírali správnou odpověd'z několika nabídnutých položek.

Box č. 10 Ukázka z testu znalostí o změnách klimatu a d. (Dove, 1996)

1. Sluneční plyny absorbují sluneční záření.

2. CO2 je nejsilnější skleníkový plyn.

3. Kdyby tu nebyl skleníkový efekt, nikdo z nás by tu nebyl.

4. Skleníkový efekt je zcela důsledkem lidské činnosti.

5. Díry v ozonové vrstvě zvyšují skleníkový efekt. 
Příklady testů, měřících obecnější environmentální vědomí studentů učitelství najdeme u Tuncera et al. (2009), Yavetze et al. (2009) či u nás Matějčka a Bartoše (2012).

Jedenácti-položkový test Tuncera et al. (2009) měl velmi dobrou reliabilitu (Cronbach alfa=0,88), odpovědi respondentů byly kódovány $0 / 1$. Test ale z části vycházel z tureckých podmínek a do českého prostředí by musel být rozsáhle adaptován (ukázka v. box č. 11).

Box č. 11 Ukázka z testu environmentálních znalostí (Tuncer et al., 2009)

- Stromy jsou obnovitelné zdroje

- Motorová vozidla jsou největším zdrojem CO.

- Baterie jsou domácí nebezpečný odpad.

Dobrou reliabilitu měl i 23-položkový test Yavetze et al. (2009), založený na výběru ze čtyř možností. Také v tomto př́padě byly některé položky specificky formulovány pro izraelské podmínky (v. box č. 12).

Box č. 12 Ukázka z testu environmentálních znalostí (Yavetz et al., 2009)

Nejvíce se v domácnosti používá voda na
a) Pití a vaření
b) Splachování toalety
c) Koupání
d) Praní

Který z následujících zdrojů energie je spojován s nejmenším poškozováním životního prostředí?
a) Uhlí
b) Zemní plyn
c) Solární energie
d) Jaderná energie

Kácení deštných pralesů zvýší
a) Fotosyntézu
b) Skleníkový efekt
c) Množství ultrafialového záření, které dosáhne zemského povrchu
d) Kyselé deště

Která z následujících možností představuje možný efekt akumulace skleníkových plynů v atmosféře?
a) Snížení množství $\mathrm{CO}_{2} v$ atmosféře
b) Snížení hladiny moří
c) Posun pouštní oblasti v Izraeli na jih
d) Zvýšená frekvence extrémních klimatických jevů 
Poslední uvedená položka v boxu č. 12 současně ukazuje možná rizika znalostních testů. Jakkoliv je možnost d) nejpravděpodobnější, nelze vyloučit i možnosti b) v důsledku globálního ochlazení jako efektu změn klimatu. Položky by proto měly být vždy důkladně ověřeny v týmu expertů.

Otevřené otázky použili v českém prostředí Matějček a Bartoš (2012). Studenti měli za úkol definovat pojmy: skleníkový efekt, Dobsonova jednotka, invazní druh, udržitelný rozvoj a ekologická stopa. Odpovědi byly následně kódovány jako "vyhovující" - "nevyhovujíci" - "nevyplněno, nebo pojem neslyšeli". V další části měli uvést, jaký vliv mají na životní prostředí jízda autem, konzumace hovězího masa a spotřeba papíru. Odpovědi byly následně kategorizovány a byla vypočítána relativní četnost položek v jednotlivých kategoriích v poměru k počtu studentů.

Celkově ale můžeme shrnout, že komplexní test, který by spolehlivě měřil proměnné související s touto oblastí, zatím u nás nemáme $\mathrm{k}$ dispozici. Evaluátorům Ize proto doporučit, aby nový test použili raději na tematicky zaměřenější oblast (tj. např. na změny klimatu), než se pokoušeli vytvořit nástroj měřící celou oblast. 


\section{PŘIPRAVENOST JEDNAT VE PROSPĚCH ŽIVOTNÍHO PROSTŘEDÍ}

Proměnné související s touto oblastí cílů (v. tab. č. 9) jsou v rámci dané věkové skupiny poměrně často měřeny. Obvyklou strategií jsou dotazníky s různými typy škál. Příklady proměnných uvádí tab. č. 10:

Tab. č. 9 Připravenost jednat ve prospěch životního prostředí v Cílech a indikátorech EVVO

\begin{tabular}{|c|c|c|}
\hline Rámcový cíl & $\begin{array}{l}\text { Vysvětlující komentář (je nutno brát } \\
\text { jako pouze ilustrativní a indikativní } \\
\text { výklad) }\end{array}$ & $\begin{array}{l}\text { Orientační příklady možností ověření, } \\
\text { popř. indikátorů (co je například možné } \\
\text { vyhodnocovat a jakým nástrojem) }\end{array}$ \\
\hline $\begin{array}{l}\text { Znalost základních } \\
\text { principů ochrany } \\
\text { životního prostředí }\end{array}$ & 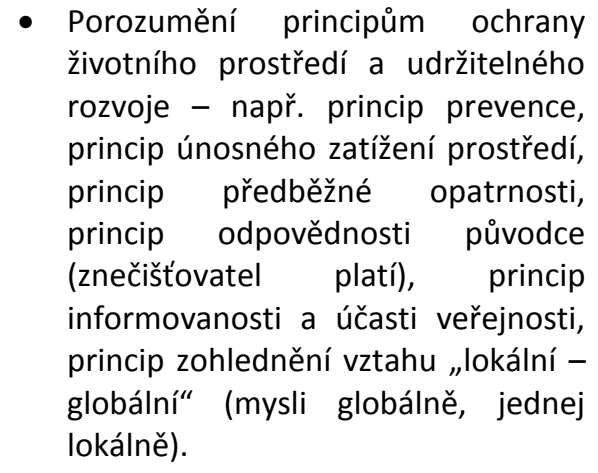 & $\begin{array}{l}\text { - Porozumění vybraným pojmům } \\
\text { (znalostní testy, rozhovory). } \\
\text { - Postoj k jednotlivým principům } \\
\text { ochrany životního prostředí a } \\
\text { k ochraně životního prostředí na } \\
\text { obecné rovině (dotazník, rozhovor, } \\
\text { esej). }\end{array}$ \\
\hline $\begin{array}{l}\text { Znalosti a dovednosti } \\
\text { potřebné pro šetrné } \\
\text { zacházení s př́rodou a } \\
\text { př́rodními zdroji }\end{array}$ & $\begin{array}{l}\text { - Osvojení dovedností pro ohleduplné } \\
\text { jednání vǔči přírodě, pro šetrný } \\
\text { pobyt v přírodě, šetrné využívání } \\
\text { prírody a nakládání s jejími } \\
\text { součástmi. } \\
\text { - Porozumění postupům a } \\
\text { technologickým řešením, která jsou } \\
\text { šetrná k životnímu prostředí zejm. } \\
\text { voblastech snižování znečištění a } \\
\text { úspor prírodních zdrojů, a schopnost } \\
\text { jejich použití - např. třídění odpadů, } \\
\text { využití druhotných surovin a } \\
\text { obnovitelných zdrojů energie, } \\
\text { šetření vodou a elektřinou, výběr } \\
\text { způsobu dopravy, zavádění systémů } \\
\text { environmentálního managementu. }\end{array}$ & $\begin{array}{l}\text { - Znalosti v uvedených oblastech } \\
\text { (znalostní testy). } \\
\text { - Dovednosti v uvedených oblastech } \\
\text { (dovednostní testy, pozorování). } \\
\text { - Přesvědčení o zvládnutí uvedených } \\
\text { dovedností (dotazníky, rozhovory). } \\
\text { - Postoj k danému chování (dotazníky, } \\
\text { rozhovory). } \\
\text { - Odhodlání k danému chování } \\
\text { (dotazník, rozhovor). } \\
\text { - Proenvironmentální chování v dané } \\
\text { oblasti (dotazník, pozorování, } \\
\text { rozhovor). }\end{array}$ \\
\hline $\begin{array}{ll}\text { Znalosti a dovednosti } \\
\text { pro } & \text { spotřebitelské } \\
\text { chování } & \end{array}$ & $\begin{array}{l}\text { - Znalost environmentálního značení } \\
\text { (ekoznačky - např. EŠV, FSC, Bio), } \\
\text { schopnost posouzení „ekologické } \\
\text { stopy“ výrobku (přepravní } \\
\text { vzdálenost, spotřeba energie, } \\
\text { recyklovatelnost apod.), etického a } \\
\text { sociálního rozměru (např. fair } \\
\text { trade). } \\
\text { - Schopnost posuzovat a předvídat } \\
\text { dopady vlastního jednání na životní } \\
\text { prostředí. }\end{array}$ & $\begin{array}{l}\text { - Znalostní a dovednostní testy, } \\
\text { dotazníky na měření přesvědčení o } \\
\text { zvládnutí dovedností, dotazníky na } \\
\text { měření souvisejících postojů, } \\
\text { dotazníky vyhodnocující chování } \\
\text { respondentů, pozorování, rozhovor } \\
\text { - Znalosti v uvedených oblastech } \\
\text { (znalostní testy). } \\
\text { - Dovednosti v uvedených oblastech } \\
\text { (dovednostní testy, pozorování). } \\
\text { - Postoj k danému chování (dotazníky, } \\
\text { rozhovory). }\end{array}$ \\
\hline
\end{tabular}




\begin{tabular}{|c|c|c|}
\hline & & $\begin{array}{l}\text { - Přesvědčení o zvládnutí uvedených } \\
\text { dovedností (dotazníky, rozhovory). } \\
\text { - Odhodlání k danému chování } \\
\text { (dotazník, rozhovor). } \\
\text { - Proenvironmentální chování v dané } \\
\text { oblasti (dotazník, pozorování, } \\
\text { rozhovor). }\end{array}$ \\
\hline $\begin{array}{l}\text { Znalosti a dovednosti } \\
\text { pro aktivní ovlivňování } \\
\text { svého okolí }\end{array}$ & $\begin{array}{l}\text { - Orientace v legislativním rámci ve } \\
\text { vztahu k životnímu prostředí a účasti } \\
\text { občanů na rozhodování (znalost } \\
\text { práv a povinností, např. právo na } \\
\text { příznivé životní prostředí, právo na } \\
\text { informace, právo na účast } \\
\text { v rozhodování) a schopnost využití } \\
\text { demokratických nástrojů na } \\
\text { prosazování ekologicky příznivých } \\
\text { rešení (např. zapojení do územního } \\
\text { plánování, do procesu EIA, do } \\
\text { správních řízení, využití petice, } \\
\text { diskuse s volenými zástupci nebo } \\
\text { kandidáty do veřejných funkcí } \\
\text { apod.). }\end{array}$ & 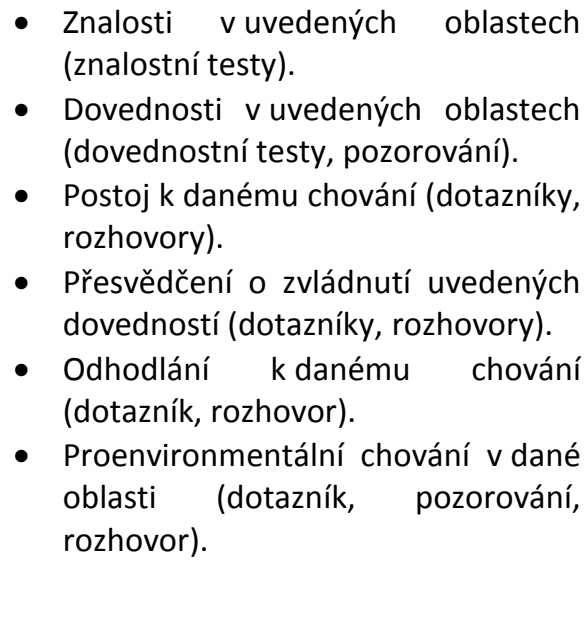 \\
\hline $\begin{array}{l}\text { Přesvědčení o vlastním } \\
\text { vlivu na předcházení a } \\
\text { řešení croblémů } \\
\text { životního prostředí }\end{array}$ & $\begin{array}{l}\text { - Motivace a ochota k zapojení do } \\
\text { řešení problémů životního prostředí. } \\
\text { - Vědomí / přesvědčení, že svým } \\
\text { jednáním mohu pozitivně ovlivnit } \\
\text { stav životního prostředí. }\end{array}$ & $\begin{array}{l}\text { - Ohnisko kontroly (dotazník, } \\
\text { rozhovor). } \\
\text { - Ochota zapojit se do konkrétních } \\
\text { akcí na ochranu životního prostředí } \\
\text { (dotazník). }\end{array}$ \\
\hline
\end{tabular}

Tab. č. 10 Proměnné pro Připravenost jednat ve prospěch životního prostředí

\begin{tabular}{|c|c|c|}
\hline Rámcový cíl & Příklady proměnných & Definice proměnných \\
\hline $\begin{array}{l}\text { Znalost základních } \\
\text { principů ochrany } \\
\text { životního prostředí }\end{array}$ & $\begin{array}{l}\text { Environmentální vědomí } \\
\text { (environmental } \\
\text { awareness) }\end{array}$ & $\begin{array}{l}\text { Znalost environmentálních problémů na globální, } \\
\text { národní i regionální úrovni, schopnost pojmenovat } \\
\text { přičiny i důsledky vyplývající z jejich ekologické, } \\
\text { sociální a ekonomické provázanosti a znalost } \\
\text { základních strategií jejich řešení. }\end{array}$ \\
\hline \multirow{3}{*}{$\begin{array}{l}\text { Znalosti a dovednosti } \\
\text { potřebné pro šetrné } \\
\text { zacházení s prrírodou a } \\
\text { prrírodními zdroji }\end{array}$} & 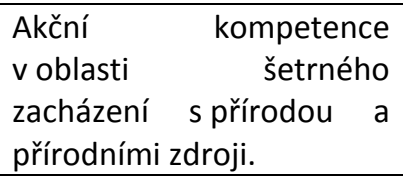 & $\begin{array}{l}\text { Znalosti a dovednosti respondenta potřebné pro } \\
\text { šetrné zacházení s prrírodou a př́rodními zdroji. }\end{array}$ \\
\hline & $\begin{array}{l}\text { Přesvědčení o zvládnutí } \\
\text { akčních } \quad \text { kompetencí } \\
\text { v oblasti šetrného } \\
\text { zacházení s přírodou a } \\
\text { prírodními zdroji. }\end{array}$ & $\begin{array}{l}\text { Přesvědčení respondenta o míre a kvalitě vlastních } \\
\text { znalostí a dovedností potřebných pro zvážení svého } \\
\text { zacházení s př́rodou a prírodními zdroji. }\end{array}$ \\
\hline & $\begin{array}{l}\text { Postoje k šetrnému } \\
\text { zacházení s prírodou a } \\
\text { prírodními zdroji. }\end{array}$ & $\begin{array}{l}\text { Pozitivní, negativní či neutrální stanovisko } \\
\text { respondenta k odpovědnému zacházení s prrírodou a }\end{array}$ \\
\hline
\end{tabular}




\begin{tabular}{|c|c|c|}
\hline & & přírodními zdroji na konkrétní či obecné rovině. \\
\hline & $\begin{array}{l}\text { Odhodlání k šetrnému } \\
\text { zacházení s přírodou a } \\
\text { prírodními zdroji. }\end{array}$ & $\begin{array}{l}\text { Míra odhodlanosti respondenta volit v konkrétním } \\
\text { případě či na obecné rovině ve svém nakládání } \\
\text { s přírodou a přírodními zdroji řešení šetrnější } \\
\text { k životnímu prostředí. }\end{array}$ \\
\hline & 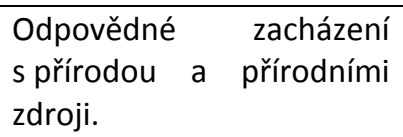 & $\begin{array}{l}\text { Četnost případů volby šetrnějšího nakládání } \\
\text { s prrírodou a prrírodními zdroji. }\end{array}$ \\
\hline \multirow[t]{5}{*}{$\begin{array}{ll}\text { Znalosti a dovednosti } \\
\text { pro } & \text { spotřebitelské } \\
\text { chování } & \end{array}$} & $\begin{array}{lr}\text { Akční } & \text { kompetence } \\
\text { v oblasti } & \text { spotřebitelského } \\
\text { chování } & \end{array}$ & $\begin{array}{l}\text { Znalosti a dovednosti respondenta potřebné pro } \\
\text { zvážení environmentálních dopadů určitého výrobku a } \\
\text { související spotřebitelské chování. }\end{array}$ \\
\hline & $\begin{array}{l}\text { Přesvědčení o zvládnutí } \\
\text { akčních } \quad \text { kompetencí } \\
\text { v oblasti spotrebitelského } \\
\text { chování. }\end{array}$ & $\begin{array}{l}\text { Přesvědčení respondenta o miře a kvalitě vlastních } \\
\text { znalostí a dovedností potřebných pro zvážení } \\
\text { environmentálních dopadů určitého výrobku a } \\
\text { související spotřebitelské chování. }\end{array}$ \\
\hline & $\begin{array}{l}\text { Postoje } \\
\text { k spotřebitelskému } \\
\text { chování. }\end{array}$ & $\begin{array}{l}\text { Pozitivní, negativní či neutrální stanovisko } \\
\text { respondenta k odpovědnému spotřebitelskému } \\
\text { chování na konkrétní či obecné rovině. }\end{array}$ \\
\hline & $\begin{array}{l}\text { Odhodlání } \\
\text { k odpovědnému } \\
\text { spotřebitelskému chování. }\end{array}$ & $\begin{array}{l}\text { Míra odhodlanosti respondenta zohlednit } \\
\text { v konkrétním případě či na obecné rovině ve svém } \\
\text { spotřebitelském chování dopady výrobků na životní } \\
\text { prostředí. }\end{array}$ \\
\hline & $\begin{array}{l}\text { Odpovědné spotřebitelské } \\
\text { chování. }\end{array}$ & $\begin{array}{l}\text { Četnost případů zakoupení či nezakoupení určitého } \\
\text { výrobku z důvodu jeho dopadu na životní prostredí. }\end{array}$ \\
\hline \multirow[t]{3}{*}{$\begin{array}{l}\text { Znalosti a dovednosti } \\
\text { pro aktivní ovlivňování } \\
\text { svého okolí }\end{array}$} & $\begin{array}{l}\text { Akční kompetence } \\
\text { v oblasti přesvědčování, } \\
\text { politického a právního } \\
\text { environmentálně } \\
\text { odpovědného chování. }\end{array}$ & $\begin{array}{l}\text { Znalosti a dovednosti respondenta potřebné pro } \\
\text { přesvědčování ostatních, využívání právních nástrojů a } \\
\text { svých politických práv pro dosažení environmentálně } \\
\text { příznivého důsledku. }\end{array}$ \\
\hline & $\begin{array}{l}\text { Přesvědčení o zvládnutí } \\
\text { akčních kompetencí } \\
\text { v oblasti přesvědčování, } \\
\text { politického a právního } \\
\text { environmentálně } \\
\text { odpovědného chování. }\end{array}$ & $\begin{array}{l}\text { Přesvědčení respondenta o míre a kvalitě vlastních } \\
\text { znalostí a dovedností potřebných pro přesvědčování } \\
\text { ostatních, využívání právních nástrojů a svých } \\
\text { politických práv pro dosažení environmentálně } \\
\text { příznivého důsledku. }\end{array}$ \\
\hline & $\begin{array}{l}\text { Postoje } \\
\text { k environmentálně } \\
\text { odpovědnému chování } \\
\text { v oblasti přesvědčování, } \\
\text { politického a právního } \\
\text { chování. }\end{array}$ & $\begin{array}{l}\text { Pozitivní, negativní či neutrální stanovisko } \\
\text { respondenta k přesvědčování, politickému či } \\
\text { právnímu environmentálně odpovědnému chování. }\end{array}$ \\
\hline
\end{tabular}




\begin{tabular}{|c|c|c|}
\hline & $\begin{array}{l}\text { Odhodlání } \\
\text { k přesvědčování, } \\
\text { politickému a právnímu } \\
\text { environmentálně } \\
\text { odpovědnému chování. }\end{array}$ & $\begin{array}{l}\text { Míra odhodlanosti respondenta přesvědčovat ostatní, } \\
\text { využívat existující právní nástroje a svá politická práva } \\
\text { pro dosažení environmentálně příznivého důsledku. }\end{array}$ \\
\hline & $\begin{array}{l}\text { Environmentálně } \\
\text { odpovědné chování } \\
\text { v oblasti přesvědčování, } \\
\text { politické či právní. }\end{array}$ & $\begin{array}{l}\text { Četnost případů přesvědčování ostatních, využití } \\
\text { existujících právních nástrojů a svých politických práv } \\
\text { pro dosažení environmentálně příznivého důsledku } \\
\text { respondentem. }\end{array}$ \\
\hline \multirow[t]{2}{*}{$\begin{array}{l}\text { Přesvědčení o vlastním } \\
\text { vlivu na předcházení a } \\
\text { řešení cyoblémů } \\
\text { životního prostředí }\end{array}$} & $\begin{array}{l}\text { Environmentální } \\
\text { odpovědnost }\end{array}$ & $\begin{array}{l}\text { Přesvědčení o svém vlivu na životní prostředí, } \\
\text { potenciálu jej pozitivně ovlivňovat a motivace } \\
\text { k odpovědnému environmentálnímu jednání }\end{array}$ \\
\hline & $\begin{array}{l}\text { Ohnisko kontroly (locus of } \\
\text { control) }\end{array}$ & $\begin{array}{l}\text { Přesvědčení o schopnosti ovlivnit svým jednáním } \\
\text { okolí. }\end{array}$ \\
\hline
\end{tabular}

Ohnisko kontroly odráží míru přesvědčení o schopnosti respondenta ovlivnit svým jednáním okolí (Hungerford \& Volk, 1990). Proměnná je zpravidla měřena dotazníkem s poměrně malým počtem položek a Likertovou škálou. Př́kladem je nástroj, který připravili Fielding a Head (2012) pro výzkum australských žáků středních škol ( $N=1529)$ a absolventů (18-24 let, N=2192). Nástroj se skládal ze tří položek využívající Likertovu škálu 1 (zcela nesouhlasím - 5 úplně souhlasím), Cronbach alfa=0,68 (v. box č. 13):

Box č. 13 Ohnisko kontroly (Fielding \& Head, 2012)

1. I já jako jednotlivec mohu svým jednáním ovlivnit životní prostředí.

2. Mohu ovlivnit rozhodování o záležitostech, které v budoucnu pomohou chránit životní prostředí.

3. Jsem jenom jeden člověk a nemohu životní prostředí nijak ovlivnit.

Odhodlanost $\mathrm{k}$ jednání může být v řadě případů dobrá alternativa k měření odpovědného environmentálního chování. Standardně se zde používají dotazníky využívající různé verze Likertovy škály.

Dillon a Gayford (1997) publikovali výzkum odhodlanosti vysokoškolských studentů k odpovědnému environmentálnímu chování založený na Ajzenově (1991) teorii plánovaného chování. Nástroj vycházel ze tř̌inácti okruhů odpovědného chování (např. recyklace skla, úspora energie doma, podpora národních či mezinárodních environmentálních organizací). Pro každý z nich měli respondenti na sedmibodové škále rozhodnout mezi dvěma póly (např. pravděpodobně/nepravděpodobně, dobře/špatně, pravda/nepravda). Ke každému okruhu pak bylo sestaveno tvrzení, zahrnující přesvědčení (Když budu doma spotřebovávat méně energie, snižím dopady na životní prostředí), motivaci k činnosti v rodině, subjektivní normu, odhodlání k jednání atd. Složitost nástroje ale pravděpodobně omezuje jeho využití v evaluační praxi.

Cordano et al. (2003) připravili pro svůj výzkum realizovaný na na množině vysokoškolských studentů (N=149) čtyřpoložkový dotazník měřící postoje k environmentální regulaci (ERA) (Cronbach alfa=0,71) a jednoduchou šesti-položkovou škálu měřící odhodlanost k proenvironmentálnímu chování (IPB) (Cronbach alfa=0,88). Oba nástroje uvádíme v boxu č. 14: 
Box č. 14 Postoje k environmentální regulaci a odhodlanost k proenvironmentálnímu jednání (IA/ERA)

(Cordano et al., 2003)

IA

1. Zákony o znečištění už zašly př́liš daleko

2. Zákony proti znečištování by měly být silněji prosazovány.

3. Musíme přijmout silnější opatření na ochranu našich přírodních zdrojů.

4. Environmentální regulace kladou neférové překážky průmyslu.

ERA

1. Podepsal bych petici na podporu přísnějších zákonů na ochranu životního prostředí.

2. Účastnil bych se protestní akce proti firmě, která poškozuje životní prostředí.

3. Zapojil bych se do protestní akce proti současnému stavu životního prostředí.

4. Plánuji zúčastnit se akce organizované environmentální organizací.

5. Rozšiřoval bych informace vydané environmentální organizací mezi moji rodinu a prátele.

6. Plánuji napsat dopis na orgán veřejné správy, aby zvýšil svoje úsilí na podporu ochrany životního prostředí.

Box č. 15 Odhodlanost k jednání (Soukup, 2001)

Jak dalece jste vy osobně ochoten/ochotna v zájmu životního prostředí

- Platit mnohem vyšší ceny

- Platit mnohem vyšší daně

- Přijmout snížení životní úrovně

Odpovědné environmentální chování bývá měřeno bud' specificky pro určitou oblast (např. spotřebitelství) či jako celek. Jednoduchý dotazník, Environmental behavior scale (EB) na jeho měření sestavili Dutcher et al. (2007). Dotazník se skládá z šesti položek popisující určitý typ chování, pro který mají respondenti vždy rozhodnout, zda se ho už někdy dělali (ano/ne). Při ověřování se ukázalo, že nástroj obsahuje dva faktory, přičemž první obsahoval čtyři položky (box č. 16 položky 1,2,5,6, Cronbach alfa=0,68) a druhý dvě (box č.16, p. 3,4 , Cronbach alfa=0,41), jednofaktorové řešení pak mělo Cronbach alfa=0,67. Dotazník byl použit na 741 majitelích pozemků v Pennsylvánii (průměrný věk 57 let, vysokoškolské vzdělání).

V rámci projektu VaVal „Hodnocení efektivity nástrojů environmentální výchovy, vzdělávání a osvěty“pro Technologickou agenturu ČR byl nástroj adaptován pro české prostředí (v. box č. 16). 
Box č. 16 Environmental behavior scale (EB) (Dutcher et al., 2007)

Už jste někdy...

1. ...svým časem či finančně přispěl/-a organizaci, která se věnuje ochraně životního prostředí či volně žijících druhů? ANO-NE

2. ...přestal/-a nakupovat nějaký produkt z důvodu jeho nepříznivého vlivu na životní prostředí? ANONE

3. ...se zúčastnil/-a veřejného slyšení či setkání věnovaného životnímu prostředí? ANO-NE

4. ...kontaktoval/-a státní instituci za účelem získání informací či podání stížnosti ohledně problému souvisejícího se životním prostředím? ANO-NE

5. ...hlasoval/-a pro kandidáta/kandidátku či proti nim z důvodu jejich stanovisek týkajících se životního prostředí? ANO-NE

6. ...nějakým způsobem změnil/-a své chování kvůli životnímu prostředí? ANO-NE

Ověřování české verze přineslo trochu odlišné výsledky. Při výzkumu na studentech pedagogické fakulty $(\mathrm{N}=100)$ se nástroj choval v podstatě stejně, jak uvádí Dutcher et al. (2007). Jednofaktorové řešení mělo hodnotu Cronbach alfa=0,68. Dvoufaktorové řešení by pro položky 1,2,5,6 mělo hodnotu Cronbach alfa=0,73 a pro položky 3,4 Cronbach alfa=0,43. Tyto výsledky se ale nepotvrdily u druhého pilotního výzkumu, který byl proveden pomoci webového rozhraní pro nespecifikované uživatele internetu, kdy výzkumný tým rozeslal svým známým prosbu o vyplnění dotazníku s žádostí o další šíření, Ize tedy mluvit o metodě „sněhové koule“ ( $N=289)$. Jednofaktorové řešení mělo tentokrát hodnotu pouze Cronbach alfa=0,56, přičemž první faktor tentokrát obsahoval položky 1-5(Cronbach alfa=0,58) a druhý se skládal ze samotné položky č. 6, která negativně korelovala s položkami 2,4 a 5 . Při rozdělení na původní dva faktory klesla interní reliabilita prvního faktoru $(1,2,5,6)$ na Cronbach alfa=0,42 a druhého $(3,4)$ na Cronbach alfa=0,44. Při zahrnutí všech respondentů ( $N=389$ ) spadla hodnota Cronbach alfa na 0,48, přičemž druhý faktor by tentokrát obsahoval položky 4 a 6 , které spolu silně negativně korelovaly. Při porovnání obou skupin respondentů se ukázalo, že se od sebe významně liší (z=-3,4, p<0.001), statisticky významný rozdíl byl nalezen na všech položkách kromě položky č. 3. Studenti ve srovnání s nespecifikovanou veřejností častěji přispívali ekologickým organizacím (1), přestali kupovat méně šetrné výrobky (2)a velmi výrazně častěji také změnili svoje chování kvůli životnímu prostředí (6). Naopak nespecifická veřejnost častěji kontaktovala instituci a volila kandidáta $(4,5)$.

Cílem dalšího ověřování bylo zjistit, zda je nástroj vhodný pro skupinu vysokoškolských studentů pedagogického zaměření. Pro další sběr dat byl nástroj rozšířen na celkem 12 položek (v. příloha č. 1). Při analýze dat od N=65 byla reliabilita nástroje vyhodnocena na Cronbach alfa=0,75, přičemž jedinou problémovou položkou byla položka č. 3 (...se zúčastnil/-a veřejného slyšení či jednání věnovaného životnímu prostředí?). Na základě provedené analýzy předpokládáme, že nástroj je ve své nové verzi (EBS-2) použitelný pro měření environmentálního chování vysokoškolských studentů. Pro použití nástroje pro další cílové skupiny by bylo nutné provést další šetření.

V České republice měřilo odpovědné environmentální chování několik dílčích sond. Dvořáčková a Ryplová (2012) vytvořili jednoduchou škálu s pěti položkami, ve které respondenti uváděli frekvenci daného chování na škále 10-1 (10 bodů - několikrát denně, 9 bodů - každý den, 8 bodů - několikrát týdně, 7 bodů - jednou týdně, 6 bodů - několikrát měsíčně, 5 bodů - jednou měsíčně, 4 body - několikrát do roka, 3 body - jednou za rok, 2 body - několikrát v životě, 1 bod - nikdy) (v. box č. 17). Reliabilita škály není uvedena. 
Box č. 17 Proenvironmentální chování (Dvořáčková \& Ryplová, 2012)

- Trrídíte odpad

- Kupujete EKO výrobky

- Kupujete BIO výrobky

- Se zapojujete do proenvironmentálních akcí

- Upřednostňujete koupi českých výrobků před zahraničními

Na podobném principu funguje Rozšiřující škála proenvironmentálního jednání, kterou sestavili Činčera a Štěpánek (2007). Respondenti měli odpovídat na škále „vícekrát-jednou-vůbec-nevím“. Reliabilita škály ale nebyla ověřována (box č. 18).

Box č. 18 Rozšiřující škála proenvironmentálního jednání (Činčera \& Štěpánek, 2007)

Za posledních šest měsíců jsem...

1. Navštívil/-a přírodu ve svém okolí.

2. Navštívil/-a př́rodu v jiné zemi.

3. Přečetl/-a jakoukoliv publikaci nebo informační zdroj o životním prostředí.

4. Finančně přispěl/-a na ochranu životního prostředí.

5. Finančně přispěl/-a na charitativní účely.

6. Podepsal/-a petici požadující lepší ochranu životního prostředí nebo se jinak písemně vyjádřil pro tento požadavek.

7. Koupil/-a výrobek s ekoznačkou.

8. Koupil/-a si dražší výrobek kvůli tomu, že byl šetrnější k životnímu prostředí.

9. Třídil/-a doma odpad.

10. Využil/-a právo na informace pro otázky související s životním prostředím.

Celkově lze shrnout, že přestože adaptace domácích nástrojů pro měření proměnných souvisejících s připraveností jednat ve prospěch životního prostředí není ještě na dostatečné úrovni, evaluátoři a výzkumníci mohou pracovat s některým z prezentovaných nástrojů. Předpokladem je prvotní ověření pro danou cílovou skupinu a případné úpravy nástroje před jeho použitím pro sběr dat.

Vyhodnocování environmentální gramotnosti cílových skupin může přinést důležité informace pro nastavení teorie připravovaného programu. Ve druhé části této metodiky se podíváme na některé strategie, které je možné použít pro získání informací o fungování programu určeného pro dospělou klientelu. 


\section{EVALUACE PROGRAMŮ PRO DOSPĚLOU KLIENTELU}

Wals $(2008,2012)$ rozlišuje mezi instrumentálním a emancipačním přístupem k environmentální výchově. Ve vztahu k dospělé klientele můžeme z tohoto dělení vyjít a zabývat se zvlášt́ programy, které jsou založeny na tréninku, jakožto plánovanému rozvoji specifických kompetencí cílové skupiny lektorem, a sociálním učení (Wals et al., 2007), jakožto nehierarchicky orientovaných programů, které jsou řízeny samotnou učící se komunitou. Typickým příkladem prvního přistupu jsou programy DVPP, ve kterých si učitelé osvojují kompetence z různých oblastí své praxe, nebo informální vzdělávací programy, např́klad v oblasti environmentální interpretace (Ham, 1992). Typickým př́kladem druhého přístupu jsou komunitně orientované programy zaměřené na vzájemné sdílení zkušeností. Následující kapitola bude proto rozdělena do tří částí. První část se bude zabývat strategiemi pro evaluaci tréninkových programů, druhá programů informálního vzdělávání a třetí komunitně orientovaných programů.

\section{TRÉNINKOVÉ PROGRAMY}

Nejznámějším modelem pro evaluaci tréninkových programů je tzv. Kirkpatrickův model. Kirkpatrick (Kirkpatrick \& Kirkpatrick, 2007) definoval čtyři základní oblasti evaluace:

- reakce, kde se hodnotí, jak účastníci reagují na seminář a jak jsou s ním spokojeni;

- $\quad$ učení, kde se hodnotí, jak tréninkový program změnil účastnické znalosti, dovednosti a postoje;

- chování, kde se hodnotí, jaká změna v chování účastníků v důsledku programu nastala a

- výsledky, kde se hodnotí dopady, které nastaly v důsledku tréninku.

V rámci tréninkových kurzů environmentální výchovy (tj. například vzdělávacích kurzů pro učitele) je důležité nezůstat pouze na reaktivní rovině a pokusit se obsáhnout dvě či více oblastí.

\section{HODNOCENÍ SPOKOJENOSTI S TRÉNINKEM}

Základním nástrojem pro hodnocení spokojenosti je písemný dotazník rozdávaný účastníkům po ukončení kurzu. Kirkpatrick (Kirkpatrick \& Kirkpatrick, 2007) doporučuje a) připravit seznam položek, které chceme hodnotit, b) používat uzavřené, kvantifikovatelné položky (např. s Likertovou škálou), c) zakončit dotazník otevřenou otázkou s žádosti o návrhy a vylepšení, d) zachovat anonymitu respondentů a e) získat odpovědi od všech účastníků. Př́klady položek jsou uvedeny v boxu č. 19.

Místo obvyklých hodnot Likertovy škály s čísly či slovy je možné použít „smajlíky“ či jinou grafickou reprezentaci číselných hodnot. Uzavřené otázky mohou být doplněny prostorem pro komentár. V dotazníku se mohou objevovat i otevřené otázky, ale pravděpodobně by neměly převažovat, protože respondenti zpravidla píši jen krátké a málo výtěžné odpovědi.

Kvantitativní sběr dat může být doplněn jinou metodou, například pozorováním či ohniskovou skupinou (focus group). Kvalitativním metodám evaluace programů pro dospělou klientelu se budeme zabývat v jiné části. 
Box č. 19 Př́klady položek pro hodnocení spokojenosti (Kirkpatrick \& Kirkpatrick, 2007)

\begin{tabular}{|l|l|}
\hline $\begin{array}{l}\text { Jak hodnotíte lektora (znalost tématu, } \\
\text { komunikační schopnosti) }\end{array}$ & výborný - velmi dobrý - dobrý - přijatelný - slabý \\
\hline Jak hodnotíte ubytovací prostředí? & výborný - velmi dobrý - dobrý - přijatelný - slabý \\
\hline Jak hodnotíte časový rozvrh? & výborný - velmi dobrý - dobrý - přijatelný - slabý \\
\hline
\end{tabular}

Jak hodnotíte lektora?

\begin{tabular}{|l|l|l|l|l|l|}
\hline & Výborný & Velmi dobrý & Dobrý & Přijatelný & Slabý \\
\hline V dodržování cílů & & & & & \\
\hline $\begin{array}{l}\text { V udržování semináře } \\
\text { zajímavého a živého }\end{array}$ & & & & & \\
\hline V komunikaci & & & & & \\
\hline $\begin{array}{l}\text { V udržování přátelského } \\
\text { postoje }\end{array}$ & & & & & \\
\hline
\end{tabular}

\begin{tabular}{|l|c|c|c|c|c|c|c|c||}
\hline & $\begin{array}{c}\text { Rozhodně } \\
\text { ano }\end{array}$ & & & $\begin{array}{c}\text { Neutrál- } \\
\text { ní }\end{array}$ & & & & $\begin{array}{c}\text { Rozhodně } \\
\text { ne }\end{array}$ \\
\hline $\begin{array}{l}\text { Obsah semináře byl } \\
\text { důležitý pro moji práci }\end{array}$ & 1 & 2 & 3 & 4 & 5 & 6 & 7 & 8 \\
\hline $\begin{array}{l}\text { Materiály byly } \\
\text { prezentovány } \\
\text { zajímavě }\end{array}$ & 1 & 2 & 3 & 4 & 5 & 6 & 7 & 8 \\
\hline $\begin{array}{l}\text { Lektor byl dobře } \\
\text { připravený }\end{array}$ & 1 & 2 & 3 & 4 & 5 & 6 & 7 & 8 \\
\hline
\end{tabular}

Celkově lze říct, že dotazníky měřící spokojenost účastníků, jakkoliv jsou nezbytnou součástí evaluace, mají často malou vypovídací hodnotu. První příčinou bývá jejich špatné zpracování. V boxu č. 20 je uveden příklad špatně zpracovaného dotazníku z domácího prostředí. Základní chybou je založení dotazníku výlučně na otevřených otázkách. Respondenti na konci semináře bývají unavení a nemají chut' psát nic závažnějšího. Závorka za položkami v boxu č. 20 uvádí kurzívou př́klady odpovědí, které se v dotazníku objevily.

Box č. 20 Příklad špatně zpracovaného dotazníku na hodnocení spokojenosti

1. Co se mi na semináři líbilo? (Byl dobře připravený, promyšlený.)

2. Co mi na semináři chybělo? (-)

3. S čím odcházím (nejdůležitější postřeh, informace, otázka)? (S materiálem pro vlastní výuku.)

4. Splnil seminář Vaše očekávání? (ano)

5. Další komentář (-) 
Druhý problém nastává v administraci. Kirkpatrick et al. (2007) velmi doporučují získat dotazníky od všech účastníků kurzu. Důvodem je získat data i od nespokojených účastníků, kteří by se jinak hodnocení vyhnuli. Třetí problém nastává s interpretací výsledků. Pro hodnocení je vhodné předem určit kritéria úspěšnosti, podle kterých budou data vyhodnocována (tj. například „více než $80 \%$ účastníků bude se seminářem spíše nebo zcela spokojeno“). Ani poté ale není zcela jednoznačné, jak kladné hodnocení interpretovat. Účastník může být spokojený, pokud jej kurz odborně posunul, ale i tehdy, pokud v něm našel potvrzení pro svoji (jakkoliv efektivní) praxi. Hluboké učení, které předpokládá změny v zažité praxi, je často provázeno negativními emocionálními reakcemi, pocitem ztráty orientace a potřebou bránit zažité postupy (Argyris, 1976, Argyris, 1995, Mezirow, 2000). Hodnocení spokojenosti je tedy třeba chápat jako samozřejmou část evaluace trénikových programů, ale současně jako část s relativně malou vypovídací hodnotou.

HODNOCENÍ ZNALOSTÍ, DOVEDNOSTÍ A POSTOJŮ

Pro hodnocení na úrovni učení doporučuje Kirkpatrick et al. (2007) používat testy a dotazníky na měření znalostí a postojů před a po programu, výkonnostní testy na měření dovedností před či pouze po programu a podle potřeby využití kontrolní skupiny.

Požadované znalosti účastníků jsou specifické pro daný typ kurzu. V evaluaci specializačního studia pro koordinátory EVVO realizovaného v rámci SSEV Pavučina byla mimo jiné ověřována znalost efektivních strategií pro sestavování programů environmentální výchovy. V dotazníku před zahájením studia a na jeho konci pak účastníci vyplňovali sérii úkolů, která ověřovala, zda rozliší vhodnou strategii od nevhodné. Následující příklad prezentuje učitelům strategii známou jako K-A-B, která je považována za neúčinnou (Hungerford \& Volk, 1990). Protože se evaluační tým obával, že by respondenti mohli otázku interpretovat odlišně, byli požádáni o vysvětlující komentář (v. box č. 21):

Box č. 21 Příklad položky ověřujícího porozumění efektivním strategiím environmentální výchovy

Vojtěch je biolog. V rámci svých hodin v páté třídě chce, aby žáci rozeznali všechny běžně rostoucí stromy, keře a květiny v regionu. Vychází z toho, že čím lépe děti znají přírodu, tím se k ní pak šetrněji chovají. Má pravdu?

Spíše ANO - Spíše NE (zakroužkujte jednu možnost)

Proč (odůvodněte jednou větou):

Mezi často hodnocené proměnné patří přesvědčení respondenta o zvládnutí daných kompetencí (self-efficacy). (Bandura, 1977, Moseley \& Reinke, 2005, Postareff, 2007, Ignat \& Clipa, 2010). Např́klad v evaluaci specializačního studia pro koordinátory EVVO byly pro hodnocení self-efficacy použity následující položky (v. box č.22). Studium se soustředilo na tři hlavní kompetence: schopnost koordinovat, plánovat a aktivně realizovat environmentální výchovu. Respondenti hodnotili na čtyřbodové Likertově škále s možnostmi „Vůbec ne - spíše ne - spíše ano - rozhodně ano":

Box č. 22 Příklad položek na hodnocení self-efficacy koordinátora environmentální výchovy

Jak byste hodnotil/-a

....sami sebe: do jaké míry jste nyní schopni koordinovat environmentální výchovu (EV) na Vaší škole?

.... sami sebe: do jaké míry jste nyní schopni plánovat EV na Vaší škole?

.... sami sebe:do jaké míry jste nyní schopni realizovat EV na Vaší škole? 
I při hodnocení této proměnné je zapotřebí zvážit, kdy se budou sbírat data, a jak výsledky interpretovat. Vyšší self-efficacy posiluje pravděpodobnost, že se respondent bude danou činností zabývat (Bandura, 1977, Moseley \& Reinke, 2005, Postareff, 2007, Ignat \& Clipa, 2010). Je ale možné, že účastníkova vstupní hladina self-efficacy neodpovídala efektivitě jeho práce a že respondent si v průběhu programu uvědomil, že musí svůj styl přehodnotit. Při nesprávném načasování pak může sběr dat proběhnout ve chvíli, kdy je respondentovo selfefficacy nízké, protože jeho původní koncepty byly otřeseny a nové se dosud nestihly vytvořit (Argyris, 1976, Argyris, 1995, Mezirow, 2000).

Hodnocení osvojených dovedností zpravidla předpokládá, že účastník splní v průběhu či na konci studia úkol, ve kterém prokáže získané kompetence. Ty pak evaluátor hodnotí podle předem daných kritérií. Pro hodnocení se často používají různé typy hodnotících tabulek. Následující příklad uvádí část hodnotící tabulky pro studenty specializačního studia pro koordinátory environmentální výchovy. $V$ rámci úkolu měli studenti analyzovat a navrhnout školní program EVVO. Př́klad (v. box č. 23) uvádí kritéria pro jedno z kritérií pro hodnocení části tohoto úkolu, analýzu stávajícího školního plánu z hlediska environmentální výchovy. Studentské práce pak nezávisle hodnotili dva hodnotitelé.

Box č. 23 Ukázka z hodnotící tabulky pro analýzu školního plánu environmentální výchovy

\begin{tabular}{|c|c|c|c|c|c|}
\hline $\begin{array}{l}\text { Kategorie / } \\
\text { Indikátor }\end{array}$ & $\begin{array}{c}\text { Nedostačující } \\
\text { úroveň }\end{array}$ & $\begin{array}{l}\text { Základní } \\
\text { úroveň }\end{array}$ & $\begin{array}{c}\text { Mírně } \\
\text { pokročilá } \\
\text { úroveň }\end{array}$ & $\begin{array}{l}\text { Pokročilá } \\
\text { úroveň }\end{array}$ & $\begin{array}{l}\text { Expertní } \\
\text { úroveň }\end{array}$ \\
\hline Rozbor ŠVP & $\begin{array}{l}\text { Rozbor ŠVP } \\
\text { chybí. }\end{array}$ & $\begin{array}{l}\text { Rozbor ŠVP } \\
\text { obsahuje } \\
\text { vlastní názory, } \\
\text { avšak chybí } \\
\text { zdůvodnění, } \\
\text { jedná se spíše } \\
\text { o dojmy, jen } \\
\text { z části se } \\
\text { vztahuje k EV. } \\
\text { Rozbor je } \\
\text { nevyvážený, } \\
\text { např. popisuje } \\
\text { pouze slabé, } \\
\text { nebo silné } \\
\text { stránky. }\end{array}$ & $\begin{array}{l}\text { Rozbor ŠVP } \\
\text { identifikuje } \\
\text { několik silných } \\
\text { i slabých míst, } \\
\text { která jsou } \\
\text { konkrétní, ale } \\
\text { opírají se } \\
\text { z části o dojmy } \\
\text { a nepodložené } \\
\text { názory autora. } \\
\text { Postihuje body } \\
\text { v ŠVP (příp. } \\
\text { RVP) podstatné } \\
\text { pro EV. }\end{array}$ & $\begin{array}{l}\text { Rozbor ŠVP } \\
\text { obsahuje } \\
\text { konkrétní silná } \\
\text { a slabá místa } \\
\text { ŠVP (příp. RVP) } \\
\text { podstatné pro } \\
\text { EV z hlediska } \\
\text { jejího obsahu a } \\
\text { funkčnosti. } \\
\text { Obsahuje } \\
\text { odůvodněné } \\
\text { názory. }\end{array}$ & $\begin{array}{l}\text { Rozbor ŠVP } \\
\text { obsahuje } \\
\text { konkrétní silná } \\
\text { a slabá místa } \\
\text { z hlediska } \\
\text { obsahu a } \\
\text { funkčnosti } \\
\text { v zastoupení } \\
\text { EV v ŠVP a RVP. } \\
\text { Obsahuje } \\
\text { závěry - } \\
\text { vyjádření } \\
\text { názoru autora } \\
\text { a návrhy } \\
\text { možností } \\
\text { řešení. Tyto } \\
\text { závěry jsou } \\
\text { podpořeny } \\
\text { znalostmi } \\
\text { různých } \\
\text { přístupů } \\
\text { v EVVO. }\end{array}$ \\
\hline
\end{tabular}


HODNOCENÍ VLIVU PROGRAMU NA CHOVÁNÍ ABSOLVENTU゚ A DLOUHODOBÉ DOPADY PROGRAMU

Kirkpatrick et al. (2007) pro měření vlivu programu na chování doporučují použít široké spektrum metod, zahrnující dotazníky, pozorování, hodnocení splněných úkolů, rozhovory či ohniskové skupiny. Je-li to možné, doporučuji využít kontrolní skupinu a měření před a po programu. Sběr dat se zpravidla provádí s větším odstupem, zpravidla kolem šesti měsíců od ukončení programu.

Box č. 24 uvádí příklad položek z dotazníku zaměřeného na sebehodnocení změny chování respondentů po programu:

Box č. 24 Ukázka položek z dotazníku na sebehodnocení změny chování (Kirkpatrick et al., 2007)

\begin{tabular}{|c|c|c|c|c|c|c|}
\hline & $\begin{array}{c}\text { Mnohem } \\
\text { lepší }\end{array}$ & $\begin{array}{c}\text { Trochu } \\
\text { lepší }\end{array}$ & $\begin{array}{l}\text { Žádná } \\
\text { změna }\end{array}$ & $\begin{array}{c}\text { Trochu } \\
\text { horší }\end{array}$ & $\begin{array}{c}\text { Mnohem } \\
\text { horší }\end{array}$ & Nevím \\
\hline $\begin{array}{l}\text { Jak byste popsal/-a svoji } \\
\text { schopnost poskytnout } \\
\text { včasnou, důležitou a } \\
\text { konstruktivní zpětnou } \\
\text { vazbu? }\end{array}$ & & & & & & \\
\hline $\begin{array}{l}\text { Jak byste popsal/-a svoji } \\
\text { schopnost jasně } \\
\text { předávat informace? }\end{array}$ & & & & & & \\
\hline
\end{tabular}

Otevřené otázky mohou přinést hlubší vhled, i když i zde platí, že respondenti zpravidla píši maximálně několik vět a je proto na místě zvážit, zda by ohnisková skupina nepřinesla více dat. $V$ evaluaci specializačního studia pro koordinátory EVVO dostali absolventi půl roku po ukončení kurzu dotazník, který ověřoval využití získaných kompetencí. Př́klad položky uvádíme v boxu č. 25 :

Box č. 25 Př́klad otevřené otázky pro hodnocení využití získaných kompetencí

Jedním z cílů studia bylo pomoci účastníkům dobře koordinovat EV (tedy motivovat, zapojovat své kolegy, propojovat výuku, poradit jim, navazovat nové kontakty, shánět finanční prostředky atd.) na své škole. Jak byste popsali svoji praxi od ukončení studia v této oblasti? V čem se změnila oproti stavu před zahájením studia?

Hodnocení poslední roviny tréninku předpokládá, že bude možné ověřit změny, které nové chování respondentů přineslo na pracovišti. Dopad mohou doložit finanční ukazatele, změna vztahů na pracovišti či změna školní praxe.

V České republice dosud chybí zkušenost s hodnocením dlouhodobého dopadu tréninkových kurzů v oblasti environmentální výchovy. Jedním z pokusů byla evaluační sonda specializačních studií pro koordinátory environmentální výchovy realizovaná zhruba půl roku od ukončení studia (Činčera, Gilar \& Sokolovičová, 2010), $v$ jejímž rámci byly hodnocené nové kurikulární dokumenty, které absolventi zpracovali. Vzhledem $\mathrm{k}$ velmi malému počtu respondentů $v$ této kvalitativní sondě byly ale výsledky pouze orientační. 


\section{VÝZNAM KURZU PRO ÚČASTNÍKY}

Zejména u dlouhodobějších programů může důležitou roli hrát to, jak účastníci kurz prožívají a jaký mu přisuzují význam. V kurzu mohou probíhat sociální procesy ovlivňující otevřenost studentů novým kompetencím, případně spoluutvářející význam prezentovaných kompetencí.

Pro takto zaměřené evaluace je na místě volit kvalitativní design, zahrnující pozorování, rozhovory, ohniskové skupiny či volné texty studentů a absolventů.

V domácím prostředí proběhly takto zaměřené evaluace na dvou ročnících specializačních studií pro koordinátory environmentální výchovy realizovaných středisky SSEV Pavučina (Činčera, Gilar \& Sokolovičová, 2010, Činčera, Kohoutová \& Sokolovičová, 2010). Zatímco první výzkum stál na kombinaci rozhovorů s absolventy a analýze jejich kurikulárních dokumentů (Činčera, Gilar \& Sokolovičová, 2010), druhý používal širokou škálu kvantitativních i kvalitativních nástrojů. Pro analýzu toho, jak studenti interpretovali průběh studia, byla použita kombinace nástrojů, zahrnující ohniskové skupiny s 6-8 respondenty v první třetině kurzu a na konci kurzu, rozhovory s koordinátory studia a volné texty od absolventů s odstupem několika měsíců od ukončení studia. Data byla následně kódována podle Glaserovy verze zakotvené teorie (Glaser, 1978, Glaser, 1998).

V boxu č. 26 uvádíme příklad struktury rozhovoru pro ohniskové skupiny vedené v první třetině kurzu (Činčera, Kohoutová \& Sokolovičová, 2010):

Box č. 26 Plán rozhovoru pro ohniskovou skupinu studentů specializačního studia v první třetině kurzu (Činčera, Kohoutová \& Sokolovičová, 2010)

1. Protože jsem nemohl být na studiu po celou dobu, zajímá mě, o co jsem přišel. Vyberte prosím jednu část, která vás nejvíce zaujala a popište mi jí. Kdybych byl moucha a kroužil nad vámi, co bych viděl, slyšel, cítil...?

2. Díky. Ted' se zkusíme vrátit úplně na začátek. Když jste se přihlásili na studium, jaká byla v té době Vaše očekávání?

a. Co z toho, co studium nabízelo, pro vás bylo nejdůležitější?

b. Co jste předpokládali, že na studiu získáte?

3. Máme zatím za sebou jen první část semináře. V jakých ohledech si myslíte, že zatím průběh odpovídá Vašemu vstupnímu očekávání?

a. V jakých ohledech se průběh od vašeho očekávání liší?

b. Doplňujíí: Jsou tyto rozdíly spíše v obsahu nebo ve formě?

c. Jaké jsou vaše převládající pocity ze studia?

4. Sešli jste se tady z různých škol, máte za sebou různé zkušenosti. Co vás ze zkušeností ostatních účastníků nejvíce zaujalo?

a. Doplňující. Jak vlastně probíhá taková neformální výměna zkušeností mezi vámi?

b. Co byste navrhovali změnit, abyste dokázali z výměny zkušeností vytěžit víc?

5. Co z toho, čím jste se zatím na semináři zabývali, považujete za prínos pro vaši práci.

a. Co se vám ze studia zatím podařilo využít?

Rozhovor sleduje zásady, které uvádí Patton (2002). Začíná odlehčující deskriptivní otázkou, která umožňuje respondentům se „rozpovídat“ a současně poskytuje první data. V bodu 3 se dostává k jádru rozhovoru, který koresponduje s evaluačními otázkami. Tyto části rozhovoru jsou pro respondenty nejtěžší, ale současně jim dávají prostor pro vyjádření svého hodnocení a prípadné nespokojenosti. $V$ bodu 4 rozhovor přechází $k$ procesům ve skupině $a v$ bodě $5 \mathrm{k}$ reflektovaným prínosům studia. Všechny hlavní otázky jsou otevřené, aby 
umožnily účastníkům se „rozpovídat“. Celkově se rozhovor soustředí na „první dojmy“ a přichází ve chvíli, kdy účastníci zažívají první střet svých očekávání a konceptů s programem.

Oproti tomu, rozhovory vedené v závěru kurzu (studium trvalo zhruba 18 měsíců) jsou orientované na význam studia jako celku. Plán ohniskové skupiny uvádíme v boxu č. 27:

Box č. 27 Plán rozhovoru pro ohniskovou skupinu v závěru specializačního studia

1. Máte za sebou téměř celé studium pro koordinátory. Kdybyste z něj měli vybrat jeden okamžik, který považujete za nejdůležitější, co by to bylo?

2. Když jste do studia vstupovali, měli jste různá očekávání. $V$ čem vás studium překvapilo?

3. V čem se Vaše očekávání nenaplnila?

4. Žádné studium není jen o rozumu, ale je i o pocitech. Jaký nejsilnější pozitivní pocit se vám spolu se studiem vybavuje? Jaký nejsilnější negativní pocit?

5. V průběhu studia jste procházeli různými úkoly, tématy, aktivitami. Učili jste se metodiku, zkoušeli si různé programy, plnili samostatné práce. Které z těchto typů aktivit považujete za nejpřínosnější pro Vaši vlastní praxi?

6. Co jste se na studiu naučili nového?

7. Co z toho, co jste se naučili, považujete za nejvíce užitečné pro Vaši praxi?

8. Co byste na studiu dělali jinak, pokud byste jej organizovali $V y$ ?

Otázky opět sledují posloupnost „události - pocity - přínosy - transfer“. Otázky jsou otevřené a nemanipulativní.

Doplňující kvalitativní data byla sebrána také pomocí volných textů šest měsíců od ukončení studia. Tento typ nástroje produkuje poměrně stručné výpovědi, ale v kombinaci s jinými nástroji a od většího počtu respondentů může být užitečný. Příklad zadání uvádíme v boxu č. 28:

Box č. 28 Příklad zadání volného textu

Každé studium je trochu jako př́běh. Má svůj začátek i konec, silná i slabá místa, propady i vrcholy. Důležité postavy i ty, které se jím jen mihly. Jste na konci příběhu Vašeho specializačního studia. Jaký to byl příběh? Chceme Vás poprosit, abyste nám v následujících deseti minutách na tuto otázku odpověděl/a. Můžete psát o studiu cokoli, co Vás napadne. Pište souvislý text (ne body), co jste napsal/a, už neopravujte a pravopisem se netrapte. Je pro nás cennější, když nám popíšete stránku či dvě Vašimi konkrétními postřehy, než abyste se snažil/a vše shrnout do jedné či dvou „vybroušených“ vět. Využijte všechen čas, až vyprší, dáme Vám vědět.

Zpracování takto získaných dat předpokládá výběr významových segmentů, kódování a vytváření širších kategorií, které nakonec umožní složit novou „teorii“ sociálních procesů ve skupině. V prípadě evaluace specializačního studia (boxy 26-28) se z analýzy vynořila centrální kategorie „vyrovnávání se s kognitivní disonancí". Nová teorie popisovala, jak počáteční očekávání hravě zaměřeného kurzu narazilo na náročně nastavený program, což účastníky vedlo k „prvotnímu šoku“, znejistění jejich prekonceptů efektivní výuky environmentální výchovy a následně k emočně náročnému procesu vedoucímu k přijetí či odmítnutí konceptů prezentovaných programem. $Z$ analýzy vyplynula řada údajů korespondující se všemi úrovněmi Kirkpatrickova 
(2007) modelu. Porozumění procesům, které se v průběhu studia odehrávaly a uvědomění si důležitosti „vybalancovat“ počáteční negativní reakce studentů představuje ale pro pozdější využití v praxi důležitější data, než míra posunu v dílčích rozvíjených kompetencích.

\section{PROGRAMY INFORMÁLNÍHO VZDĚLÁVÁNÍ}

V muzeích, zoologických a botanických zahradách i v přírodních oblastech je nabízen velký počet programů informální vzdělávání v oblasti environmentální výchovy pro širokou veřejnost. Programy tohoto typu zahrnují naučné stezky, výstavy, terénní programy s průvodcem aj. Stejně jako kterékoliv jiné, i tyto programy je žádoucí evaluovat a ověrovat tak jejich smysl.

\section{ENVIRONMENTÁLNÍ INTERPRETACE}

Environmentální interpretace je v širokém slova smyslu komunikace mezi interpretem (lektorem, průvodcem), návštěvníkem (turistou, účastníkem, žákem) a místem (přírodní oblastí, kulturním objektem, muzeem atd.). V užším významu je to tedy typ informálního vzdělávání, které je určeno pro návštěvníky určité lokality (Ham, 1992, Back \& Cable, 2002, Tilden, 2007). Environmentální interpretace se tedy na rozdíl od ostatních programů environmentální výchovy prímo vztahuje k určité lokalitě, má zpravidla informální charakter a je často určena pro rozmanitější věkovou skupinu. Na rozdíl od programů environmentální výchovy také nemusí probíhat za př́mé účasti lektora (terénní interpretativní programy), ale může být zprostředkována pomocí naučných stezek, výstav či jiných forem.

Podle Knappa (1997) a Knappa et al. (1997) mají programy environmentální interpretace stejné cíle, jako programy environmentální výchovy. Ve vztahu k oblastem cílů popsaných v Cílech a indikátorech EVVO (Broukalová a kol., 2012) se tedy vztahují nejenom ke vztahu k místu, ale i ke všem ostatním oblastem. Hodnotit je tedy možné nejenom spokojenost návštěvníků, ale i získané znalosti, postoje, přesvědčení o dovednostech či odhodlanost k proenvironmentálnímu chování.

Specifickými obtížemi pro jejich evaluace může být zejména a) neochota návštěvníků vyplnit dvakrát stejný dotazník, b) neochota vyplňovat př́liš dlouhé nástroje, c) obtížné zajištění stejných podmínek u lektorem nezprostředkovaných programů (např. turisté mohou začít procházku po naučné stezce na různých místech). Navzdory tomu jsou korektně provedené evaluace možné. Jak dokládá Munro (2008), z 21 hodnocených evaluací interpretativních programů jich 10 použilo pre/post design a osm kontrolní skupinu.

Příkladem řešení evaluace programu, kde nebylo možné zadat respondentům oba testy, je evaluace vlivu interpretativního programu na znalosti související s ochranou korálového útesu v mořském národním parku v Austrálii (Madin a Fenton, 2004). V rámci programu jsou návštěvníci převáženi na útes lodí. Pro sběr dat provedli evaluátoři náhodné rozdělení turistů na poloviny. První polovina dostala vědomostní test před návštěvou útesu, druhá při cestě zpět.

Evaluace výstav či naučných stezek může kromě dotazníků či testu účinně využívat také pozorování. Evaluátor může vyhodnocovat, u kterých exponátů výstavy či cedulí naučné stezky se návštěvník zastaví, případně na jak dlouho (Diamond et al., 2009). Podobná strategie byla využita při evaluaci naučných stezek v Libereckém kraji (Beňková \& Činčera, 2010). V rámci evaluace byly porovnávány dvě naučné stezky využívající interaktivní prvky se srovnatelnou dvojicí stezek bez interaktivních prvků. Evaluace využívala několik nástrojů. Prvním byl vědomostní test, který dostávali návštěvníci stezky (v. box č. 29) ${ }^{9}$ Druhým bylo pozorování. Evaluátorka u

\footnotetext{
${ }^{9}$ Test byl sestaven zvlášt' pro každou stezku, ale obsahoval srovnatelné otázky.
} 
vybraného zastavení každé stezky sledovala, jak velký podíl návštěvníků se u něj zastaví a kolik u něj stráví času. ${ }^{10}$

Box č. 29 Příklad jednoduchého vědomostního testu pro naučnou stezku Jedlový důl (Beňková \& Činčera, 2010)

1. Jaké jsou původní lesy zdejší oblasti? A jehličnaté B smíšené C listnaté

2. Který strom je charakteristický pro Jedlový důl? A modřín $\mathrm{B}$ břiza $\mathrm{C}$ jedle

3. Jak se jmenuje potok protékající Jedlovým dolem?

4. Napište prosím, jaké 2 druhy květiny jsou typické pro zdejší oblast?

5. Napište, které 2 druhy ptáků se zde vyskytují?

6. Jakou rostlinu má CHKO Jizerské hory ve znaku? A suchopýr B pampeliška C úpolín

Jinou možností je hodnocení lektorem neprovázeného interpretativního programu podle předem určených kritérií. Ty mohou souviset s jeho formální stránkou (např. počet slov, rozmístění obrázků, barevné řešení), obsahovou správností, zacílením (provázanost hlavního tématu s dílčími) či kvalitou komunikace (jazykové prostředky, počet myšlenek). $v$ České republice ale dosud standardizovaný nástroj pro hodnocení tohoto typu programů nebyl vytvořen.

\section{INFORMÁLNÍ PROGRAMY V ZOOLOGICKÝCH A BOTANICKÝCH ZAHRADÁCH}

Zoologické a botanické zahrady realizují řadu programů se vztahem k cílovým oblastem environmentální výchovy, jako je vztah k př́rodě či environmentální problémy a konflikty (ochrana druhů). Pro evaluace platí stejná omezení, jako u interpretativních programů. Podobné jsou i strategie k jejich překonání.

Například Lukas a Ross (2005) zkoumali znalosti a postoje návštěvníků ZOO o gorilách a šimpanzích (N=1000). Porovnávali, jestli se liší odpovědi respondentů ve vztahu ke druhu opice, četnosti návštěv ZOO, pohlaví a místa, kde vyplnili dotazník: u vchodu či východu ze zoologické zahrady. Dotazník se skládal z 19 znalostních otázek typu pravda/nepravda a 28 položek měřících postoje respondentů k opicím.

Swanagan (2000) použil kombinaci nástrojů k tomu, aby zjistil, jaký vliv měla návštěva informálního programu (výstavy) zoologické zahrady na postoje návštěvníků k obchodování se slonovinou. Návštěvníci dostávali u východu tři různé nástroje: jednoduchý dotazník, který mimo jiné indikoval jejich účast na programu, nabídku petice pro zpřísnění regulace obchodu s ohroženými druhy a lístek, na který mohli napsat svůj názor na problém.

Celkově tedy můžeme shrnout, že přestože evaluace informálních programů přináší specifické obtíže, je v nich možné používat podobné nástroje a strategie, jako v ostatních programech environmentální výchovy.

\footnotetext{
${ }^{10}$ Protože mnozí turisté chodí ve skupinách (např. rodiče s dětmi), byly při pozorování porovnávány jednotky (skupiny), nikoliv každý návštěvník zvlášt'.
} 


\section{KOMUNITNĚ ORIENTOVANÉ PROGRAMY}

Jako "komunitně orientované programy" zde chápeme programy, které vychází z emancipačního přístupu environmentální výchovy (Wals, 2008, 2012), uplatňují principy sociálního učení (Wals et al., 2007), nejsou řízeny lektorem, ale samotnou učíci se komunitou. Programy tohoto typu vznikají jako reakce profesní či lokální komunity na určitý problém. Programy nemají předem určené cíle (respektive mají cíle na poměrně obecné úrovni) a komunita si je vytváŕí sama. Programy nemají lektora, který by vybíral vhodné aktivity, obsah je vyjednáván v rámci komunity, ač skupina může mít svého facilitátora. Komunitně orientované programy, které vznikají na lokální úrovni, zpravidla řeší problémy udržitelného rozvoje ve své lokalitě. Profesně orientované komunity řeší problémy související s jejich odbornou praxí či zájmem (tzv. communities of practice) (Wenger, 2000). Př́kladem programu realizovaného v rámci profesně orientované komunity je veletrh programů ekologické výchovy, který je každoročně pořádán v rámci SSEV Pavučina.

Protože cíle komunitně orientovaných programů nejsou dány předem, nejsou evaluace zaměřené na ověřování cílů př́liš použitelné (je ovšem možné hodnotit dlouhodobé př́nosy programu, například vztah k místu, ohnisko kontroly). Komunity navíc mohou být poměrně malé a jedinečné. Evaluace se proto zpravidla zaměřuje na proces učení a jeho reflexi členy komunity.

Evaluace zpravidla vycházejí z kvalitativního designu, využívajícího formát případové studie, př́padně akčního výzkumu (Hayward et al., 2007, Rist et al., 2006, Schneider et al., 2009).

Například Hayward et al. (2007) analyzoval procesy sociálního učení, které nastaly u členů místních organizací zapojených do procesu posuzování vlivu plánovaného vodního kanálu na životní prostředí. Pro výzkum použil formát komparativní případové studie, využívající analýzu dokumentů, polostrukturované rozhovory a pozorování respondentů v průběhu jejich schůzek i účasti na veřejných projednáváních.

Evaluátor často není od programu oddělený, ale může částečně splývat s facilitátorem programu. Measham (2009) popisuje, jak se v programu rozvíjejícím zemědělské praktiky australských farmářů stal probíhající evaluační proces součástí sociálního učení. $V$ průběhu programu evaluátor několikrát sbíral data pomocí ohniskových skupin uspořádaných se zapojenými farmáři. V průběhu diskuse farmáři reflektovali svoje pocity a vyměnili si zkušenosti s implementací nových postupů do praxe. Evaluace se tak stala přirozenou součástí programu.

Domácí zkušenosti s evaluací komunitně orientovaných programů v oblasti udržitelného rozvoje a environmentální výchovy u nás zatím chybí. Na základě zahraničních výzkumů Ize evaluátorům doporučit kvalitativní design a maximální důraz na situační responsivitu výzkumu. 


\section{PERSPEKTIVA}

Dospělí, učitelé, vychovatelé či rodiče, mohou být důležitým zdrojem informací o programu, určeném pro žáky. Dostávají se tím do role respondentů. Pro získání jejich úhlu pohledu na program je pak možné využít kvalitativní i kvantitativní postupy.

Kvantitativní řešení předpokládá využití jednoduchých dotazníků, které (typicky učitelé) dostanou po ukončení programu. Pokud předpokládáme větší počet respondentů (například program se vícekrát opakuje), jsou vhodnější uzavřené otázky s prostorem pro komentáře a možná doplnění. Otázky mohou směřovat na spokojenost učitelů s programem (v. box č. 30) nebo na učitelem předpokládaný př́nos programu pro žáky (v. box č. 31):

Box č. 30 Příklad otázek hodnotících spokojenost učitele s programem (program Badatelé.cz)

Podle Vašeho názoru byla lekce pro žáky (zakroužkujte vždy jednu možnost):

velmi náročná - spíše náročná - spíše snadná - velmi snadná

Komentujte prosím př́kladem něčeho, co jste v hodině viděl/-a či slyšel/-a:

velmi zábavná - spíše zábavná - spíše nudná - velmi nudná

Komentujte prosím př́kladem něčeho, co jste v hodině viděl/-a či slyšel/-a:

věkově zcela přiměřená - spíše přiměřená - spíše nepřiměřená - zcela nepřiměřená

Komentujte prosím př́kladem něčeho, co jste v hodině viděl/-a či slyšel/-a:

Box č. 31 Příklad otázek hodnotících přínos programu pro žáky (dotazník PSS, Strážci Země)

5) Myslím, že Strážci Země pomohli mým žákům:

Rozhodnè

souhlasim
Spiše
souhlasím

Spíše

nesouhlasím nesouhlasím
Zvýšit jejich porozumění ekologickým konceptům.

Pracovat společně jako tým.

Být vůči sobě navzájem vnímavější.

Zvýšit svoji osobní nezávislost.

Být vnímavější k prírodě.

Cítit se lépe $v$ přírodě.
O

O

O

O

O

$\mathrm{O}$ o

o

o

0

o

o

$\mathrm{O}$

Změnit vliv ieiich chování na životní prostředí. 
Kvalitativní řešení zpravidla předpokládá rozhovor s dospělými respondenty, nejčastěji provedený s určitým odstupem od programu. Rozhovory se opět přepisují a kódují.

Kvalitativní strategie je náročná na čas, peníze i zpracování, ale dává šanci získat hluboká data, která z dotazníku zpravidla nedostaneme. Značnou finanční úsporu mohou přinést rozhovory vedené pomocí Skype či jiného programu, další programy umožňuji rozhovor nahrávat do souboru či zpomalovat přehrávanou nahrávku. I tak je ale třeba počítat s tím, že přepis je několikanásobně časově delší, než samotný rozhovor (cca 7-10x, podle rychlosti přepisu a kvality nahrávky). Box č. 32 uvádí příklad části přepsaného rozhovoru evaluátora s učitelkou, která hodnotí své zkušenosti s použitím metodické publikace věnované globálním problémům:

Box č. 32 Ukázka přepisu části rozhovoru

Otázka: Chtěl jsem se na začátku ještě zeptat, kdybyste z těch zkušeností, které jste dělala, měla vybrat nějaký jeden nejsilnější okamžik, který by to byl?

Odpověd': Nejsilnější okamžik. Tam je to ten Krok vpřed. Takže děcka si uvědomily, že můžou existovat otroci $v$ dnešní době. To byl šok, a ještě to říkal jeden chlapec, který je romského původu, a on je v té komunitě takový jakoby hodně důležitý, jednak chodil do té školy poctivě, a i se učil, byl celkem ukázněný, pro něho to byla hrozná pohroma, že on je právě ta osoba, která stojí na nejnižším žebříčku tam ze všech.

Otázka: Na nejnižším žebříčku. V té hře myslíte?

Odpověd': No, jako v té situaci, že on se do toho dostal, pro něho to bylo nepředstavitelné.

\section{Otázka: Vzpomenete si, jak na to reagoval? Co říkal?}

Odpověd': Nechtěl o tom mluvit, nechtěl se toho zúčastnit, a když jsem mu jako řekla, aby teda řekl tu svou osobu, kterou měl ztvárňovat, tak jeho se to vlastně dotklo. On to bral ještě jakoby jako osobní pohanu, ne, že to existuje, že to tak je, ale ještě, že on to měl jakoby ještě teda znázornit.

Evaluátor v příkladu začíná připravenou otázkou, která dává respondentce možnost reflektovat průběh práce s učebnicí. Ta ve své odpovědi poskytla velmi cenná data, otevírající téma efektu lekce na žáky a jejich emočních reakcí na prezentovaný problém. V následující otázce evaluátor zopakoval klíčové slovo z poslední části výroku a požádal o potvrzení, že správně rozumí myšlence. Respondentka upřesnila svůj výrok a současně jej doplnila o další aspekt („nepředstavitelné“). Evaluátor rozvíjí dál téma a snaží se získat další, popisné informace o incidentu.

Pokud porovnáme data, která evaluátor získá z boxu $31 \mathrm{~s}$ daty z boxu 32, vidíme velmi podstatné rozdíly. Z boxu 31 získá evaluátor učitelovo hodnocení efektu programu na žáky. Při získání dostatečného počtu respondentů pak může tento efekt statisticky vyhodnotit a získat tak „čísla“ dokumentující míru efektu programu na žáka. $Z$ boxu č. 32 evaluátor získá popis události, která se odehrála v jedné skupině a týkala se jediného žáka. Pokud by podobné zkušenosti byly zaznamenány i v dalších skupinách, evaluátor by na jejich základě mohl začít vytvářet „teorii“ analyzující, jak program ve třídách funguje. V prvním prípadě tedy zjistí míru efektu (podle hodnocení učitele), ve druhém vhled do procesů a neplánovaných dopadů na žáky.

Z boxu č. 32 je také zřejmé, proč je při evaluacích důležitá flexibilita a schopnost evaluátora reagovat na daný kontext a probíhající události. Pokud by evaluátor postupoval podle fixně připraveného sledu otázek, ztratil by důležitá data, popisující zmíněnou událost. $V$ důsledku by data mohl chybně kódovat a vyvozovat z nich nesprávné závěry. 


\section{ZÁVĚR}

Metodika uváděla př́klady strategií pro evaluaci jednotlivých rámcových cílů environmentální výchovy pro programy nabízené věkové skupině dospělých účastníků. Přestože metodika byla ve shodě se zadáním projektu zpracována jako samostatný dokument, pro hlubší porozumění doporučujeme seznámit se i $\mathrm{s}$ dalšími souvisejícími texty.

V rámci řešení výzkumného úkolu „Hodnocení efektivity nástrojů environmentálního vzdělávání, výchovy a osvěty (EVVO)" je vydávána trojice postupně navazujících metodik:

- Metodika pro hodnocení programů environmentální výchovy pro předškolní a mladší školní věk

- Metodika pro hodnocení programů environmentální výchovy pro starší školní věk a střední školy.

- Metodika pro hodnocení programů environmentální výchovy pro dospělé účastníky.

Všechny tři metodiky jsou zpracovány stejným způsobem, obsahují některé společné části a vycházejí ze stejného vymezení proměnných pro evaluaci.

V rámci projektu „Hodnocení efektivity nástrojů environmentálního vzdělávání, výchovy a osvěty (EVVO)” dále vycházejí následující studie:

- Střediska ekologické výchovy mezi teorií a praxí. Studie analyzuje, jakým způsobem česká střediska ekologické výchovy zabezpečují efektivitu svých programů a jaké faktory je ovlivňují ve volbě přijatých rozhodnutí.

- Environmentální výchova. Studie vymezuje a charakterizuje základní pojmy v oblasti environmentální výchovy. Popisuje ověřené strategie pro rozvíjení jednotlivých oblastí cílů environmentální výchovy a diskutuje existující problémy.

Projekt současně navazuje na výsledky předchozích projektů. Za klíčové publikace, které vytvářejí jeho kontext, Ize označit následující:

- Cíle a indikátory EVVO (Broukalová a kol., 2012). Dokument vznikl na základě podnětu a potřeb Ministerstva životního prostředí jako výsledek konsensu domácí profesní komunity $v$ oblasti environmentální výchovy. Vymezuje a charakterizuje jednotlivé oblasti cílů a rámcové cíle environmentální výchovy.

- Doporučené očekávané výstupy průřezového tématu environmentální výchova (Pastorová a kol., 2011a,b). Publikace vydané Výzkumným ústavem pedagogickým uvádí příklady očekávaných výstupů environmentální výchovy pro základní školy a gymnázia. Převádí tedy obecné cíle do konkrétní a ověřitelné podoby, vhodné pro školní výuku.

- Evaluace programů environmentální výchovy (Činčera, 2010). Metodika pro vedení evaluačního výzkumu programů environmentální výchovy. Publikaci je možné chápat jako společný úvod pro trojici výše uvedených metodik.

Všechny uvedené texty (metodiky, studie i doporučující dokumenty) odrážejí snahu o nové uchopení environmentální výchovy, které by podpořilo účinnou a kritickou reflexi domácích i zahraničních zkušeností a celkový kvalitativní posun oboru. Věríme, že i předkládaná studie tuto ambici odráží a bude užitečná nejenom pro výzkumníky, ale i pro praktickou část odborné komunity. 


\section{LITERATURA}

Argyris, C. (1976). Single-Loop and Double-Loop Models in Research on Decision Making. Administrative Science Quarterly, 21(3), 363-375. Retrieved from http://www.jstor.org/stable/2391848?origin=crossref http://dx.doi.org/10.2307/2391848

Argyris, C. (1995). Action science and organizational learning. Journal of Managerial Psychology, 10(6), 20-26. Retrieved from http://www.emeraldinsight.com/10.1108/02683949510093849 http://dx.doi.org/10.1108/02683949510093849

Adomssent, M., \& Michelsen, G. (2006). German academia heading for sustainability? Reflection on policy and practice in teaching, research and institutional innovation. Environmental education research, 12(1), 85-99. Retrieved from http://www.tandfonline.com/doi/abs/10.1080/13504620500527758 http://dx.doi.org/10.1080/13504620500527758

Ajzen, I. (1991). The Theory of Planned Behavior. . Organizational Behavior and Human Decision Process, 50, $179-211$.

Amburgey, J. W., \& Thoman, D. B. (2012). Dimensionality of the New ecological paradigm: issues of factor structure and measurement. Environment and Behavior, 44(2), 235-256. Retrieved from http://eab.sagepub.com/cgi/doi/10.1177/0013916511402064 http://dx.doi.org/10.1177/0013916511402064

Ardoin, N. M., Schuh, J. S., \& Gould, R. K. (2012). Exploring the dimensions of place: a confirmatory factor analysis of data from three ecoregional sites. Environmental Education Research, 18(5), 583-607. Retrieved from http://www.tandfonline.com/doi/abs/10.1080/13504622.2011.640930 http://dx.doi.org/10.1080/13504622.2011.640930

Back, L. \& Cable, T, (2002). Interpretation for the 21st century. Champaign. : Sagamore publishing.

Bandura, A. (1977). Self-efficacy: Toward a Unifying Theory of Behavioral Change. Psychological Review, 84(2), 191-215. Retrieved from http://content.apa.org/journals/rev/84/2/191 pmid:847061 http://dx.doi.org/10.1037/0033-295X.84.2.191

Bennett, D. B. (1989). Evaluating Environmental Education in Schools. A practical guide for teachers. : UNESCO UNEP, Division of Science, Technical and Environmental Education. Retrieved from http://unesdoc.unesco.org/images/0006/000661/066120eo.pdf

Beňková, V., \& Činečera, J. (2010). Prožitkové naučné stezky jako prostředek environmentální interpretace krajiny. Envigogika, 5(2), Retrieved from http://www.envigogika.cuni.cz/index.php/Envigogika/article/view/51 http://dx.doi.org/10.14712/18023061.51

Boyes, E., Chambers, W., \& Stanisstreet, M. (1995). Trainee primary teachers' ideas about the ozone layer. Environmental Education Research, 1(2), 133-145. Retrieved from http://www.tandfonline.com/doi/abs/10.1080/1350462950010201 http://dx.doi.org/10.1080/1350462950010201

Broukal, V., Toušková, B., \& Broukalová, L. (2012). Výroční zpráva 2011. Praha: Sdružení středisek ekologické výchovy Pavučina.

BROUKALOVÁ L a kol, (2012). Cíle a indikátory pro environmentální vzdělávání, výchovu a osvětu v České republice. Praha: Ministerstvo životního prostředí České republiky. Retrieved from http://www.mzp.cz/cz/cile indikatory evvo dokument 
Casakin, H., \& Billig, M. (2009). Effect on settlement size and religiozity on sense of place in communcal settlements. Environment and behavior, 41(6), 821-835. Retrieved from http://eab.sagepub.com/cgi/doi/10.1177/0013916508329944 http://dx.doi.org/10.1177/0013916508329944

Cordano, M., Welcomer, S. A., \& Scherer, R. F. (2003). An analysis of the predictive validity of the new ecological paradigm scale. The Journal of Environmental Education, 34(3), 22-28. Retrieved from http://www.tandfonline.com/doi/abs/10.1080/00958960309603490 http://dx.doi.org/10.1080/00958960309603490

Cox, J. R. (2009). Environmental communication and the public sphere. Washington: SAGE.

Činčera, J., \& Bezouška, A. (2007). Vliv environmentální profilace středních škol na proenvironmentální postoje a jednání žáků. Envigogika, 2(3), Retrieved from

http://www.envigogika.cuni.cz/index.php/Envigogika/article/view/20

http://dx.doi.org/10.14712/18023061.20

ČINČERA, J., GILAR, P. and SOKOLOVIČOVÁ, J., (2010). Specializační studium pro koordinátory environmentální výchovy, vzdělávání a osvěty: interpretace a efektivita z pohledu absolventů. Envigogika, 5(1), Retrieved from http://www.envigogika.cuni.cz/index.php/Envigogika/article/view/47

http://dx.doi.org/10.14712/18023061.47

Činčera, J., Kohoutová, K. and Sokolovičová, J., (2010). Účastníci specializačního studia pro koordinátory environmentální výchovy: očekávání, hodnocení a první př́nosy. Envigogika, 5(3), Retrieved from http://www.envigogika.cuni.cz/index.php/Envigogika/article/view/55

http://dx.doi.org/10.14712/18023061.55

Činčera, J. and Štěpánek, P., (2007). Výzkum ekologické gramotnosti studentů středních odborných škol. Envigogika, 2(1), Retrieved from http://www.envigogika.cuni.cz/index.php/Envigogika/article/view/12 http://dx.doi.org/10.14712/18023061.12

Činčera, J. (2010). Metodika evaluace programů environmentální výchovy. Envigogika, 5(3), Retrieved from http://www.envigogika.cuni.cz/index.php/Envigogika/article/view/149 http://dx.doi.org/10.14712/18023061.149

Daudi, S. S. (2000). Environmental literacy: A challenging concept for neo-literate communities?. Washington: NAAEE conference proceedings.

Diamond, J., Luke, J. J., \& Uttal, D. H. (2009). Practical evaluation guide. Tool for museums and other informal educational settings. Plymouth: Plymouth: Altamira Press.

Dillon, P. J., \& Gayford, C. G. (1997). A psychometric approach to investigating the environmental beliefs, intentions and behaviours of pre-service teachers. Environmental Education Research, 3(3), 283-297. Retrieved from http://www.tandfonline.com/doi/abs/10.1080/1350462970030303 http://dx.doi.org/10.1080/1350462970030303

Disinger, J. F. (1997). Environment in the K-12 Curriculum: An Overview. Environmental Education. Teacher Ressource Handbook. A Practical Guide for K-12 Environmental Education. Thousand Oaks: Corwin, 23-44.

Disinger, J. F., \& Roth, C. F. (1992). Environmental literacy. Environmental literacy. ERIC Clearinghouse for Science Mathematics and Environmental Education, ED3512012, Retrieved from http://www.ericdigests.org/1992-1/literacy.htm 
Dove, J. (1996). Student teacher understanding of the greenhouse effect, ozone layer depletion and acid rain. Environmental Education Research, 2(1), 89-100. Retrieved from http://www.tandfonline.com/doi/abs/10.1080/1350462960020108 http://dx.doi.org/10.1080/1350462960020108

Dunlap, R. E. (2008). The New environmental paradigm scale: from marginality to worldwide use. The Journal of environmental education, 40(1), 3-18. Retrieved from http://www.tandfonline.com/doi/abs/10.3200/JOEE.40.1.3-18 http://dx.doi.org/10.3200/JOEE.40.1.3-18

Dunlap, R. E., \& Van_liere, K. D. (1978). The „new environmental paradigm“: A proposed instrument and preliminary results. Journal of Environmental Education, 9(4), 10-19.

Dunlap, R. E., Van_liere, K. D., Mertig, A. G., \& Johnson, R. E. (2000). Measuring endorsement of the new ecological paradigm: A revisited NEP scale. Journal of Social Issues, 56(3), 425-442. Retrieved from http://doi.wiley.com/10.1111/0022-4537.00176 http://dx.doi.org/10.1111/0022-4537.00176

Dutcher, D., Finley, J., Luloff, A., \& Johnson, J. (2007). Connectivity with nature as a measure of environmental values. Environment and Behavior, 39(4), 474-493. Retrieved from http://eab.sagepub.com/cgi/doi/10.1177/0013916506298794 http://dx.doi.org/10.1177/0013916506298794

Dvořáčková, S. and Ryplová, R., (2012). Sonda environmentální gramotnosti studentů přírodovědně a ekologicky zaměřených oborů na Pedagogické fakultě JU. Envigogika, 7(3), Retrieved from http://www.envigogika.cuni.cz/index.php/Envigogika/article/view/77 http://dx.doi.org/10.14712/18023061.77

Ernst, J. A., Monroe, M. C., \& Simmons, B. (2009). Evaluating your environmental education program. A workbook for practitioners. Washington: NAAEE.

Fielding, K. S., \& Head, B. W. (2012). Determinants of young Australians' environmental actions: the role of responsibility attributions, locus of control, knowledge and attitudes. Environmental Education Research, 18(2), 171-186. Retrieved from http://www.tandfonline.com/doi/abs/10.1080/13504622.2011.592936 http://dx.doi.org/10.1080/13504622.2011.592936

Fitzpatrick, J. L., Sanders, J. R., \& Worthen, B. R. (2004). Program Evaluation. Alternative Approaches and Practical Guidelines. Boston: Pearson Education.

Franěk, M. (2012). Nature Relatedness Scale. Český překlad nástroje. Envigogika, 7(1), Retrieved from http://www.envigogika.cuni.cz/index.php/cz/recenzovane-clanky/2012/envigogika-2012-vii-1/660-naturerelatedness-scale-cesky-preklad-skaly-merici-spojeni-s-prirodou

Franěk, M. (2006). Výzkum antropocentrických a biocentrických postojů k prírodě v české populaci. In STREJČKOVÁ, Emilie. Výzkum odcizování člověka přirodě : Závěrečná zpráva [online]. Praha: Toulcův dvưr, 2006.,

FRECHTLING, J. et. al., (2002). The 2002 User-Friendly Handbook for Project Evaluation. The National Science Foundation.. . Retrieved from http://www.nsf.gov/pubs/2002/nsf02057/nsf02057.pdf

Glaser, B. G. (1978). Theoretical Sensitivity: Advances in the Methodology of Grounded Theory. San Franciso. Mill Valley, CA: Sociology Press.

Glaser, B. G. (1998). Doing Grounded Theory: Issues and Discussions. Mill Valley: Sociology Press.

Goldman, D., Yavetz, B., \& Pe'er, S. (2006). Environmental literacy in Teacher training in Israel: Environmental Behavior of New Studies. The Journal of Environmental Education, 38(1), 3-23. Retrieved from http://www.tandfonline.com/doi/abs/10.3200/JOEE.38.1.3-22 http://dx.doi.org/10.3200/JOEE.38.1.3-22 
Ham, S. H. (1992). Environmental interpretation: A practical guide for people with big ideas and small budgets. Colorado: Fulcrum Publishing.

Hayward, G., Diduck, A., \& Mitchell, B. (2007). Social Learning Outcomes in the Red River Floodway Environmental Assessment. Environmental Practice, 9(4), 239-250. Retrieved from

http://www.journals.cambridge.org/abstract_S1466046607070561

http://dx.doi.org/10.1017/S1466046607070561

Hsu, S. J., \& Roth, R. E. (1998). An assessment of environmental literacy and analysis of predictors of responsible environmental behavior held by secondary teachers in the Hualien area of Taiwan. Environmental Education Research, 4(3), 229-249. Retrieved from

http://www.tandfonline.com/doi/abs/10.1080/1350462980040301 http://dx.doi.org/10.1080/1350462980040301

Hungerford, H. R., \& Volk, T. L. (1990). Changing Learner Behavior through Environmental Education. The Journal of Environmental Education, 21(3), 8-21. Retrieved from http://www.tandfonline.com/doi/abs/10.1080/00958964.1990.10753743 http://dx.doi.org/10.1080/00958964.1990.10753743

Ignat, A. A., \& Clipa, O. (2010). The Impact of Self-Efficacy and Locus of Control on the Professional Development of the Teachers. Buletinul Universitatii Petrol-Gaze din Ploiesti, 12(1), 180-185.

Kirkpatrick, D. L., \& Kirkpatrick, J. D. (2007). Implementing the four levels. A practical guide for effective evaluation of training programs. Berrett-Koehler Publishers: San Franciso: Berrett-Koehler Publishers.

Knapp, D., Volk, T. L., \& Hungerford, H. R. (1997). The identification of empirically derived goals for program development in environmental interpretation. The Journal of Environmental Education, 3(3), 24-34. Retrieved from http://www.tandfonline.com/doi/abs/10.1080/00958964.1997.9942826

http://dx.doi.org/10.1080/00958964.1997.9942826

Knapp, D. (1997). Environmental Education and Environmental Interpretation: The Relationships. National Association for Interpretation, 3, 349-356.

Kudryavtsev, A., Stedman, R. C., \& Krasny, M. E. (2012). Sense of place in environmental education. Environmental Education Research, 2(18), 229-250.

Kusters, C. S. L. (2011). Making evaluation matter: A practical guide for evaluators. Wageningen: Centre for development and innovation. Wageningen university.

Kyle, G., Graeffe, A., \& Manning, R. (2005). Testing the dimensionality of place attachment in recreational settings. Environment and Behavior, 37(2), 153-177. Retrieved from http://eab.sagepub.com/cgi/doi/10.1177/0013916504269654 http://dx.doi.org/10.1177/0013916504269654

LaLONDE, R., \& Jackson, E. L. (2002). The New Environmental Paradigm scale: Has it outlived its usefulness. The Journal of Environmental Education, 32(4), 28-37. Retrieved from http://www.tandfonline.com/doi/abs/10.1080/00958960209599151 http://dx.doi.org/10.1080/00958960209599151

LaTROBE, H. L., \& Acott, T. G. (2002). A modified NEP/DSP environmental attitudes scale. The Journal of Environmental Education, 32(1), 1-12.

Lukas, K. E., \& Ross, S. R. (2005). ZOO visitor knowledge and attitudes toward gorillas and chimpanzes. The Journal of environmental education, 36(4), 33-48. 
Lundmark, C. (2007). The new ecological paradigm revisited: anchoring the NEP scale in environmental ethics. Environmental Education Research, 13(3), 329-347. Retrieved from http://www.tandfonline.com/doi/abs/10.1080/13504620701430448 http://dx.doi.org/10.1080/13504620701430448

Madin, E. M. P., \& Fenton, D. Mark, (2004). Environmental Interpretation in the Great Barrier Reef Marine Park: An Assessment of Programme Effectiveness. Journal of Sustainable Tourism, 12(2), 121-137. Retrieved from http://www.tandfonline.com/doi/abs/10.1080/09669580408667228 http://dx.doi.org/10.1080/09669580408667228

Matějčeek, T. and Bartoš, J., (2012). Environmentální gramotnost učitelů a studentů učitelství. Envigogika, 7(2), Retrieved from http://www.envigogika.cuni.cz/index.php/Envigogika/article/view/75 http://dx.doi.org/10.14712/18023061.75

Mayer, F. S., Frantz, M., Bruehlman-senecal, C., E,, , \& Dolliver, K. (2009). Why is nature beneficial? The role of connectedness to nature. Environment and behavior, 41(5), 607-645. Retrieved from http://eab.sagepub.com/cgi/doi/10.1177/0013916508319745 http://dx.doi.org/10.1177/0013916508319745

Mayer, S. F., \& Frantz, C. M. (2004). The connectedness to nature scale: A measure of individuals' feeling in community with nature. Journal of Environmental Psychology, 24(4), 503-515. Retrieved from http://linkinghub.elsevier.com/retrieve/pii/S0272494404000696 http://dx.doi.org/10.1016/j.jenvp.2004.10.001

Measham, T. G. (2009). Social Learning Through Evaluation: A Case study of Overcoming Constraints for Management Dryland Salinity. Environmental Management, 43, 1096-1107.

Mezirow, J. (2000). Learning to think like an adult. Core concepts of transformation theory. In Mezirow, Jack et. al. (ed.) (2000): Learning as Transformation. Critical Perspectives on a Theory in Progress. San Francisco: JosseyBass, 3-33.. : Progress. San Francisco: Jossey-Bass.

Morrone, M., Mancl, K., \& Carr, K. (2001). Development of a metric to test group differences in ecological knowledge as one component of environmental literacy. The Journal of Environmental Education, 32(4), 33-43. Retrieved from http://www.tandfonline.com/doi/abs/10.1080/00958960109598661 http://dx.doi.org/10.1080/00958960109598661

Mosely, C., \& Reinke, K. (2005). The Effect of Teaching in an Outdoor Environmental Education Program on Elementary Pre-service Teachers' Environmental Education Self-Efficacy and Outcome Expectancy. In B. Simmons (Ed.) Preparing Effective Environmental Educators. Washington: NAAEE P. 35-58.

Munro, J. K., \& Morrison-saunders, A. (2008). Environmental interpretation evaluation in natural areas. Journal of ecotourism, 8(1), 1-14. Retrieved from http://www.tandfonline.com/doi/abs/10.2167/joe137.0 http://dx.doi.org/10.2167/joe137.0

Nisbet, E. K., Zelenski, J. M., \& Murphy, S. A. (2009). The Nature relatedness scale. Linking individuals' connection with nature to environmental concern and behavior. Environment and Behavior, 41(5), 715-740. Retrieved from http://eab.sagepub.com/cgi/doi/10.1177/0013916508318748 http://dx.doi.org/10.1177/0013916508318748

PASTOROVÁ, M. a kol., (2011). Doporučené očekávané výstupy. Metodická podpora pro výuku průřezových témat na základních školách. Praha: Výzkumný ústav pedagogický. Retrieved from http://www.vuppraha.cz/nova-publikace-divize-vup-\%E2\%80\%93-doporucene-ocekavane-vystupy-prozakladni-skoly 
PASTOROVÁ, M. a kol., (2011). Doporučené očekávané výstupy. Metodická podpora pro výuku prüřezových témat v gymnáziích. Praha: Národní ústav pro vzdělávání, školské poradenské zařízení a zařízení pro další vzdělávání pedagogických pracovníků. Retrieved from http://digifolio.rvp.cz/artefact/file/download.php?file=35427\&view=4001

Patton, M. Q. (2002). Qualitative Research and Evaluation Methods.. Thousand Oaks, Calif: Sage.

Patton, M. Q. (2008). Utilization-Focused Evaluation. Thousand Oaks. Beverly Hills: Sage.

Postareff, L. (2007). Teaching in Higher Education. From Content-focused to Learning-focused Approaches to Training. Helsinki: University of Helsinki.

Pe', E. R., Goldman, S., D,, , \& Yavetz, B. (2007). Environmental literacy in teacher training: attitudes, knowledge, and environmental behavior of beginning students. The Journal of Environmental Education, 39(1), 45-59. Retrieved from http://www.tandfonline.com/doi/abs/10.3200/JOEE.39.1.45-59 http://dx.doi.org/10.3200/JOEE.39.1.45-59

Rist, S., Chiddambaranathan, M., Escobar, C., \& Wiesmann, U. (2006). It was Hard to Come to Mutual Understanding ..." -The Multidimensionality of Social Learning Processes Concerned with Sustainable Natural Resource Use in. India, Africa and Latin America. Syst Pract Act Res, 19, 219-237.

Rossi, P. H., Lipsey, M. W., \& Freeman, H. E. (2004). Evaluation. A Systemic Approach. Beverly Hills: Thousand Oaks: Sage.

Schovajsová, J. (2010). Současný stav environmentální výchovy na základních školách - vybrané aspekty environmentální gramotnosti dětí mladšího školního věku. Disertační práce. : Olomouc: Univerzita Palackého.

Schneider, F., Fry, P., Lederman, T., \& Rist, S. (2009). Social Learning Processes in Swiss Soil Protection - The "From Farmer. Social Learning Processes in Swiss Soil Protection - The "From Farmer - To Farmer" Project. Human Ecology, 37, 475-489.

Schultz, P. W. (2001). The structure of environmental concern: Concern for self, other people, and the biosphere. Journal of Environmental Psychology, 21(4), 327-339. Retrieved from http://linkinghub.elsevier.com/retrieve/pii/S0272494401902270 http://dx.doi.org/10.1006/jevp.2001.0227

Simmons, B. (2008). Designing Evaluation for Education Projects. Office of Education and Sustainable Development.. . Retrieved from http://wateroutreach.uwex.edu/use/documents/NOAAEvalmanualFINAL.pdf

Soukup, P. (2001). ISSP: životní prostředí.. Praha: Sociologický ústav Akademie věd České republiky.

Stables, A., \& Bishop, K. (2001). Weak and Strong Conceptions of Environmental Literacy: implications for environmental education. Environmental Education Research, 7(1), 89-97. Retrieved from http://www.tandfonline.com/doi/abs/10.1080/13504620125643 http://dx.doi.org/10.1080/13504620125643

Stokking, H., Van_aert, L., Meijberg, W., \& Kaskens, A. (1999). Evaluating Evironmental Education. IUCN Commission on Education and Communication CEC., Retrieved from http://www.iucn.org/wp2003/books/pdf/cec4.pdf

Swanagan, J. S. (2000). Factors influencing ZOO visitors' conservation attitudes and behavior. The Journal of Environmental Education, 31(4), 26-31. Retrieved from http://www.tandfonline.com/doi/abs/10.1080/00958960009598648 http://dx.doi.org/10.1080/00958960009598648

Tilden, F. (2007). Interpreting Our Heritage. Chapell Hill: University of North Carolina. 
Tuncer, G., Tekkaya, C., Sungur, S., Cakiroglu, J., Ertepinar, H., \& Kaplowitz, M. (2009). Assessing pre-service teachers' environmental literacy in Turkey as a mean to develop teacher education programs. International Journal of Educational Development, 29(4), 426-436. Retrieved from http://linkinghub.elsevier.com/retrieve/pii/S073805930800120X http://dx.doi.org/10.1016/i.ijedudev.2008.10.003

Van Petegem, P., \& Blieck, A. (2006). The environmental worldview of children: a cross-cultural perspective. Environmental Education Research, 12(5), 625-635. Retrieved from http://www.tandfonline.com/doi/abs/10.1080/13504620601053662 http://dx.doi.org/10.1080/13504620601053662

Vikan, A., Camino, C., Biaggio, A., \& Nordvik, H. (2007). Endorsement of the new ecological paradigm: a comparison of two Brazilian samples and one Norwegian sample. Environment and Behavior, 39(2), 317-228. Retrieved from http://eab.sagepub.com/cgi/doi/10.1177/0013916506286946

http://dx.doi.org/10.1177/0013916506286946

Wals, A. (2012). Learning our way out of unsustainability: The role of environmental education. In Clayton, S. The Oxford Handbook of Environment and Conservation. Oxford: Oxford university press, 628-644.. Oxford: Oxford university.

Wals, A., Geerling-eijff, F., Hubeek, F., Van_der_kroon, S., \& Vader, J. (2008). All mixed up? Instrumental and emancipator learning toward a more sustainable world: considerations for EE policymakers. Applied Environmental Education and Communication, 7(3), 55-65. Retrieved from http://www.tandfonline.com/doi/abs/10.1080/15330150802473027 http://dx.doi.org/10.1080/15330150802473027

2007, W. A. E. J. (2007). Social learning: Towards a sustainable world: principles, perspectives, and praxis. Netherland: Wageningen Academic, Wageningen.

Wenger, E. (2000). Communities of Practice and Social Learning Systems. Communities of Practice and Social Learning Systems. Organization, 7(2), 225-246.

Wholey, J. S., Hatry, H. P., \& Newcomer, K. E. (2004). Handbook of Practical Program Evaluation. San Francisco: Jossey-Bass.

Wright, J. M. (2008). The Comparative Effects of Constructivist Versus Traditional Teaching Methods on the Environmental Literacy of Postsecondary Nonscience Majors. Bulletin of Science, Technology \& Society, 28(4), 324-337. Retrieved from http://bst.sagepub.com/cgi/doi/10.1177/0270467608319638 http://dx.doi.org/10.1177/0270467608319638

Yavetz, B., Goldman, D., \& Pe'er, S. (2009). Environmental literacy of pre-service teachers in Israel: a comparison between students at the onset and end of their studies. Environmental education research, 15(4), 393-415. Retrieved from http://www.tandfonline.com/doi/abs/10.1080/13504620902928422 http://dx.doi.org/10.1080/13504620902928422 
PŘÍLOHA Č. 1 EBS - 2

Dobrý den,

Dovolujeme si Vás poprosit o pomoc s ověřováním dotazníku, který bude využíván pro výzkumy v oblasti životniho prostréedí. Odpovězte prosím pravdivě na dále uvedené otázky. Dotazník je anonymní a bude zpracován statisticky tak, že odpovědi žádného respondenta nebude možné přiradit ke konkrétní osobě.

Děkujeme za spolupráci,

Jan Činčera, Technická univerzita v Liberci

Odpovězte prosím na všechny následující otázky. Zakroužkujte prosím vždy jen jednu možnost, která platí: ANO nebo NE.

Príklad

Už jste někdy...

...koupil/-a BIO potravinu?

ANO - NE

Odpověd'znamená, že NE, ještě nikdy jsem si BIO potravinu nekoupil.

...koupil úspornou zářivku?

(ANO) $-N E$

Odpověd'znamená, že ANO, už jsem někdy úspornou zářivku koupil.

\begin{tabular}{|c|c|}
\hline Už jste někdy... & \\
\hline $\begin{array}{l}\text {...svým časem či finančně přispěl/-a organizaci, která se věnuje ochraně životního prostředí či } \\
\text { zviŕat a přírody? }\end{array}$ & ANO - NE \\
\hline ...přestal/-a nakupovat nějaký produkt z důvodu jeho nepříznivého vlivu na životní prostředí? & ANO - NE \\
\hline ...se zúčastnil/-a veřejného slyšení či jednání věnovaného životnímu prostředí? & ANO - NE \\
\hline $\begin{array}{l}\text {...kontaktoval/-a úřady za účelem získání informací či podání stížnosti ohledně problému } \\
\text { souvisejícího se životním prostředím? }\end{array}$ & ANO - NE \\
\hline $\begin{array}{l}\text {...hlasoval/-a pro kandidáta/kandidátku či proti nim z důvodu jejich stanovisek týkajících se } \\
\text { životního prostředí? }\end{array}$ & ANO - NE \\
\hline ...nějakým způsobem změnil/-a své chování, abyste pomohl/-a životnímu prostředí? & ANO - NE \\
\hline ...někoho přesvědčoval/-a, aby udělal něco pro životní prostředí? & ANO - NE \\
\hline $\begin{array}{l}\text {...koupil/-a výrobek šetrnější k životnímu prostředí, i když stál víc peněz než běžné podobné } \\
\text { výrobky? }\end{array}$ & ANO - NE \\
\hline $\begin{array}{l}\text {... změnil/-a něco ve svém pokoji, bytě či domě především proto, abyste pomohl/-a životnímu } \\
\text { prostředí? }\end{array}$ & ANO - NE \\
\hline ... učil/-a děti odpovědnému chování k životnímu prostředí? & ANO - NE \\
\hline ...byl/-a na dobrovolné brigádě na ochranu přírody? & ANO - NE \\
\hline ...podepsal/-a petici zaměřenou na ochranu životního prostředí? & ANO - NE \\
\hline
\end{tabular}


Jste:

MUŽ - ŽENA (zakroužkujte)

Váš věk:

.. (dopište)

Děkujeme za Váš čas a spolupráci! 
Vyšlo s podporou projektu TAČR Hodnocení efektivity nástrojů environmentálního vzdělávání, výchovy a osvěty (EVVO). Vydal a technická úprava BEZK a Agentura Koniklec, Praha, 2013.

Recenzovali: Mgr. Petr Daniš (Sdružení TEREZA), Mgr. et Mgr. Michal Medek (Středisko ekologické výchovy Kaprálův mlýn). 